\title{
National archives' priorities: an international overview
}

\author{
Sara Martínez-Cardama ${ }^{1}$ (D) Ana R. Pacios ${ }^{1}$ D
}

Accepted: 24 June 2021 / Published online: 15 July 2021

(c) The Author(s) 2021, corrected publication 2021

\begin{abstract}
This discussion of national archives' present priorities affords an overview of the areas meriting their greatest attention. It is based on an analysis of 18 strategic plans and 41 vision statements found for the 159 national archives affiliated with the International Council on Archives' regional branches that provide public access to these documents on their websites. Improvement in access to and conservation and digitisation of the respective collections are convergent items in such plans and statements. Other strategies including protection for the national heritage and collective memory are also identified in some developing countries where the national archive is the mainstay of cultural and intellectual life. Strengthening national archive authority as the governing institution that guides a country's archival policy, another issue found in both plans and statements, infers the need to heighten archives' social and institutional role in their respective countries. The article identifies what is deemed good practice in cultural institution transparency management by describing what these institutions do and how. The scant presence of strategic plans on national archives' websites is regretted, however, for it deprives citizens of information on the action planned for the years to come and precludes any international extrapolation of the present findings.
\end{abstract}

Keywords National archives $\cdot$ Strategy $\cdot$ Strategic plan · Vision statement Transparency

Sara Martínez-Cardama

Smarti1@bib.uc3m.es

Ana R. Pacios

areyes@bib.uc3m.es

1 Department of Library and Information Science, University Carlos III of Madrid, c/Madrid 126, 28903 Getafe, Spain 


\section{Introduction}

Nearly, all countries in the world over keep archives to conserve national collective memory while providing support for and attesting to governmental activities. That historicist conceptualisation of archives as instruments for State building, with roots reaching back to the French Revolution, remains in place today as a rule. In many countries, however, national archives cannot or cannot yet be instituted for reasons either of destruction or dispersal, generally across former colonial agencies (Franks and Bernier 2018; Karabinos 2018). Although all national archives systematically select and conserve documents, their social and economic environments as well as their historical and archival traditions differ substantially.

Such duties aside, today's technologies and digitisation afford a very promising backdrop for expanding archives' activity, ranging from providing and coordinating a national records management system to documenting all areas of modern governance (Wilson 2018) and including the preservation of new web-based forms of expression by managing and coordinating web archive services (Espley et al. 2014) or positioning themselves as essential partners in the country's education and culture by capitalising on their collections (Seo 2010).

National archives' near future can be gleaned from a review of planning tools such as strategic plans or vision statements. This overview of national archives' present priorities was inspired by other similar studies conducted on different types (national, public etc.) of libraries that have yielded a snapshot of the state-of-play on the continental, national or regional scale (e.g., Pacios and Martínez-Cardama 2019; Pacios 2007; Kostagiolas et al. 2009). Those studies analysed the plans published by libraries on their websites, in the understanding that they may be deemed transparency indicators insofar as they list intended endeavours, their timing and the resources to be deployed to build such a future, even if unpredictable.

The absence of similar studies for national archives prompted this study, which attempts to answer the following research questions:

R.Q.1: Do national archives practise strategic planning?

R.Q.2: What are national archives' present priorities and the preferred targets for their efforts?

R.Q.3: Do the strategies pursued by national archives differ significantly from country to country?

The paper aims to provide a worldwide overview of national archives' priority lines of action by analysing the strategic plans and vision statements accessible on their websites. Those documents are regarded as reliable sources of information on the strategies in place at archives as organisations. The institutions analysed were chosen from among the member archives affiliated with the regional associations listed on the International Council of Archives (ICA) website. 


\section{Review of the literature}

The route charted by an organisation, its aspirations and priorities, can be ascertained from its strategic plan, an indispensable document that sets out how an organisation intends to fulfil its mission and materialise its vision. Vision statements, together with an institution's mission and values, are usually the result of several key procedural steps involved in strategic planning (Calder 2014) and hence generally form part of the content of the plan. The plan itself is a look into the future which, while not necessarily real, affords a view of the course the organisation aspires to follow (Thornberry 1997, p.29) and its intended position at any given time. It is the 'expression of a dream concerning a future desired state' (Özdem 2011, p. 1889).

Strategic plans, presently published on the websites of all manner of organisations, have been shown by some authors to constitute an indication of transparency and accountability (Cunningham et al. 2011). They are also mandated by transparency legislation in place in some countries, such as Spain's Transparency Act (Sect. 6.2), which requires public institutions and bodies to publish 'annual and pluri-annual plans and programmes establishing specific objectives as well as the activities, resources and timing deemed necessary to reach the respective goals' (Ministerio de la Presidencia 2013).

Planning as a technique and a necessity has been defended by many academics, ever since Peter Drucker contended that strategic planning is necessary because prediction is uncertain, and policy-makers must be alert to the future implications of today's decisions. For the father of management, the essence of planning is to adopt decisions with an understanding of their future significance, for timing is determined by, not the determinant of, such understanding (Drucker 1981, 1987, 1989). Planning is necessary for organisations of whatsoever size, as none has unlimited resources. Planning is indisputably imperative for institutions such as archives that are custodians of historic memory, inasmuch as it defines the effect of present decisions on heritage processing, conservation and dissemination on the conveyance of that legacy to future generations in optimal condition.

\section{Strategic planning and national archives}

Planning benefits any kind of organisation, archives included. According to the UK National Archives' website (undated): 'Thorough planning is essential for good information management. You need to secure support from senior management for this work and ensure that you have the right people involved across your organisation. You should also have a clear understanding of your business requirements and compliance requirements under legislation such as the Public Records and Freedom of Information Acts'.

Professionals working in many countries have expressed support for planning throughout archival history. Wilsted and Nolte (1991, p. 27) contended that 'strategic planning takes a broad view of the needs and aspirations of an archival program.... In 1984, Carl Newton noted in his book Strategic Planning for records 
management and archives, noted that a 'strategic planning approach to the activities which make up a records management programme is an unfamiliar one in Britain' (p. 1) and urged archive services to plan, highlighting the advantages of doing so. Williams (2006, p.201) also referred to this approach in Chapter 7 entitled 'Managing an archive service'. This author referred to planning archives as a service or organisational unit, whereas Newton's remarks were geared more directly to records management.

The book entitled La gestion d'un centre d'archives compiles reflections on planning by a series of archive managers. Couture and Grimard (2003, p. 64) identify a need for long-term planning and deem this to be the most pertinent of management activities. They believe that managers of a cultural institution such as an archive, like those of goods retailers or service vendors, must define a vision and strategic guidelines while planning programmes and activities (p. 71). Along those same lines, Huot and Gareau (2003, p. 86) note that before undertaking any specific records management activity, archive services should plan how it will be conducted and such planning should be a duty incumbent on any manager, irrespective of the size of the archive at issue. Garon (2003, pp. 230-231), in turn, drawing from experience as archivist at the Quebec national archives, states that the manager of any national archive service assumes planning as one of their many responsibilities, with strategic management as an essential element.

Boadas i Raset (2006, p. 455) notes in connection with planning that 'any archive service, no matter how modest or how sparse their resources, should formulate a strategic plan consisting in a detailed and systematic list of their objectives, the timing envisaged for and the policies and measures designed to reach such objectives, along with control systems and tools to assess the results'.

Prominent archive-related organisations such as the International Council on Archives (ICA) can be seen to deploy this technique. ICA has defined a series of strategic objectives or essential activities in ICA: Strategic Direction 2008-2018 (ICA 2008), as an attempt to guide the activities of ICA members throughout the world. Those guidelines translate into six strategic targets: Raising Awareness, Influencing the Development and Use of New Technologies, Building Capacity in the Records and Archives Profession, Strengthening the ICA Network, Improving the Performance and Accountability of ICA and Building Partnerships. Its vision, set out in the same document, 'aspires to convince key decision-makers and the general public that effective records and archives management is an essential precondition for good governance, the rule of law, administrative transparency, the preservation of mankind's collective memory, and access to information by citizens'.

The results of that policy, describing the degree to which the objectives set out in the organisation's Business Plan, 2009-2010 were met (ICA 2010), are available only through May 2010. After that date, no information is provided on the association's website of any subsequent follow-through on its planning activities. Nonetheless, ICA has specific strategies and programmes in place in addition to its general international strategy. Its five-year Africa Programme, for instance, is 'aimed at strengthening the regional branch network in Africa, reinforcing national archives to advocate their vital role in government and support curriculum development at university-level recordkeeping education' (ICA 2015). 
That programme is indicative of the Council's engagement with and interest in cooperation and development in Africa. The documents involved attest to the strategic approach adopted by ICA, an organisation whose membership includes archival institutions and archivists the world over, when defining its objectives to defend effective records management and the physical protection of the written heritage, all of which should encourage its member associations to also work to strategy. A strategic plan found for the ESARBICA region (2018-2021) focuses particularly on issues such as the preservation and management of digital records, training, archive repatriation and the furtherance of the written heritage through inter-country partnering. Despite that initiative, however, none of the websites kept by the national archives of the countries in the region (Botswana, Eritrea, Ethiopia, Kenya, Madagascar, Mauritius, Mauritania, Mozambique, Namibia, South Africa, South Sudan, Swaziland and Uganda) carries information on its own strategic plan.

Outside of the ICA's efforts, geared to archives the world over in general and some requiring special action, such as in Africa, in particular, the search for studies on strategic planning in national archives yields very patchy results. The impression drawn from the papers retrieved is that planning is applied to very specific tasks such as digitisation, disaster prevention, use of space, preservation, social media and so on. Some authors have undertaken case studies of specific archive planning experience such as at NARA, the Norwegian National Archive (Bearman 1996; Herstad 1998). Other studies have focused on archives in certain regions such as those authored by Saurombe (2020) and Ngulube and Tafor (2006), both on African archives. The former analyses two dissemination endeavours undertaken in the ICA region known as ESARBICA, covering eastern and southern Africa. The latter reviews institutional management of public records and archives in that same region. Yet other authors such as Seol (2008) study strategic planning for archival information services in the National Archives of Korea (NAK).

The vision statement, in turn, an element usually included in strategic plans, is deemed a factor instrumental to an organisation's future success. Evans and Alire (2013, p. 92) suggest that it 'should be appealing to the staff, the service community and all other stakeholders'.

Some studies have found empirical evidence of the beneficial impact of these statements on organisational results and staff satisfaction and motivation (Shipley and Michela 2006), even in not-for-profit organisations (Landau et al. 2006) and academic libraries (Riggs 1998). Some of the features shared by many such statements include conciseness, clarity, future orientation, stability, challenge, abstractness and desirability or ability to inspire (Kantabutra and Avery 2010, p. 39).

No papers were located on the analysis of archive vision statements or assessments of national archives as a whole, areas in which case studies and specific descriptions of good practice prevail. One exception to that rule is to be found in Jang (2012), who compares the Australian, Canadian, Korean, UK and US national archives' websites, with the vision statement as one of the items assessed, attesting to the utility of including this element on archival websites. Ceeney (2008) specifically states that the UK National Archives' vision statement and strategy must be updated every 5 to 10 years to adapt to the digital environment. 


\section{Methodology}

The first step in the procedure deployed for this study, conducted in June 2020, consisted of a search for national archives' strategic plans and vision statements. These documents were sought on the respective websites, grouped in keeping with ICA geographic criteria to better identify the similarities and differences among archives located in a given region (https://www.ica.org/en/ica-regionalbranches): ALA (Asociación Latinoamericana de Archivos), ARBICA (Arab Regional Branch), CARBICA (Caribbean Regional Branch), CENARBICA (Central Africa Regional Branch), EASTICA (East Asian Regional Branch), ESARBICA (Eastern and Southern Africa Regional Branch), EURASICA (Eurasia Regional Branch), EURBICA (European Regional Branch), NAANICA (North American Archival Network), PARBICA (Pacific Regional Branch), SARBICA (Southeast Asian Regional Branch), SWARBICA (South and West Asian Regional Branch) and WARBICA (West African Regional Branch).

That methodological decision was based on the ICA premise that each branch has its own identity, leadership and focus. It consequently proved useful for drawing possible inferences about strategies for action shared by the national archives in a given region, as expressed in their respective strategic plans.

An initial drawback in this first search was that some of the websites accessible from ICA were out of date. Searches had therefore to be run on stable archive websites separately, an exercise attesting to the ephemerality of national archives' digital presence. One source of information for identifying archives was an article by Franks and Bernier (2018), which contains the following information on each: duties, organisational chart, services, digital infrastructure, accessibility and other items specific to each institution. The European EHRI project (https:// portal.ehri-project.eu/), in turn, while essentially carrying information on the Holocaust, proved to be very helpful for determining the location, history and present status of some national historic archives. With the destruction of national archives in the wake of natural disasters or war (Kuwait, Bosnia and Herzegovina), collections have been spread across different institutions, with the disappearance of the national archive as a stable body. Some Central African countries, in turn, have yet to create a national archive.

Although the ICA website claims that the association is present in 199 countries, an inventory of the members of each regional branch yielded a total of 159 , the targets of the present analysis.

The criterion for including a given strategic plan was its accessibility on the respective website and validity in the year the search was conducted (2020). The content of all the plans compiled was then analysed. More specifically, information was retrieved on the elements defining the areas to be explored, as follows: challenges, goals, priorities, strategic priorities, strategic objectives, long-term objectives, strategic pillars and guidelines. An ad hoc subject classification was subsequently established, coding each item under a subject category defined on the grounds of an analysis of the terms most frequently used (Titscher et al. 
2002). A graphic was then generated to identify the most prominent trends and better visualise the findings.

In addition to strategic plans, the analysis covered vision statements as elements that explain an organisation's aspirations and the position it seeks to occupy in the future. Together with mission statements, such documents should inform the organisation's strategy. The vision statements studied, which were identified on the occasion of the search and compilation of the strategic plans, included both those forming part of and those separate from the latter. Their analysis was based on keywords drawn from the sub-themes or topics defined in the statement alluding to the future pursued by the archive. That approach also revealed trends in the similarities among certain subject areas. The literal wording used in the vision statements was respected, although on occasion terms very close in meaning such as archives and records management or access and use were classified under a single category. Other formulas such as 'pride of the nation' and 'national pride' were merged for the intents and purposes of classification. The data were processed with word cloud-generating software for ready visualisation and interpretation. Stemming and the elimination of commonly used words were deployed to facilitate text and statement processing. Given the forward-looking focus that should characterise such statements, account was also taken of the presence of words alluding to the future such as 'posterity', verbs in future tense or reference to specific times, such as a given year.

Inasmuch as the methodology for this study was based on strategic plans and vision statements located on archives' websites, the findings are conditioned by such presence and public accessibility. In other words, some archives may have plans or statements not published on their websites. Neither document was located on the Norwegian archive's site, for instance, although the vision statement was mentioned in a presentation titled 'Re-designing the National Archives of Norway', delivered by Director Inga Bolstad (2019) at one of the sessions of ICA's 2019 Congress, inferring that it must exist. Moreover, not all the plans accessible from archives' websites provide the same degree of detail, for they are versions normally intended for users and much more abridged than the original documents. The findings are consequently indicative of trends but cannot be extrapolated to the universe defined in this study.

Other aspects inherent in plans, such as their implementation and possible amendments under certain circumstances (resource shortcomings, leadership changes, reluctance and so on), must also be considered and may even entail changes in some priorities. The plans analysed here are documents published on websites with no indication of possible amendments, even though strategies are neither static nor immobile but change with needs and circumstances.

\section{Results}

The search conducted on the 159 ICA members' websites yielded a total of 18 strategic plans (11.32\%) and 41 vision statements (25.78\%) (see Appendix 1 and 2 for the list and respective URLs). The findings are grouped by ICA geographic area in Table 1. 
The sub-sections below deal separately with strategic plans and vision statements.

\section{Strategic plans}

The 18 strategic plans analysed were found for countries in four ICA regions: ALA (seven plans), EURBICA (four), NAANICA (two), PARBICA (two) and SARBICA (one). Inasmuch as the Iran national archive's strategic plan is accessible from its intranet only, to the exclusion of the public at large, it was excluded from the study. The 71 strategic objectives listed on the 18 strategic plans downloaded and subsequently analysed were grouped under 24 subject categories indicative of trends (Fig. 1). Analysis also revealed that the number of strategies, priorities or objectives listed in individual plans ranges from two to seven, with three as the value with the highest frequency.

These documents are not always entitled 'strategic plan', although that is the term most often used. All the other denominations observed are nonetheless indicative of a specific outline for action and the priorities pursued (Appendix 1). The Irish archive's title, 'archives framework' deviates farthest from the rest. In France, the document bears none of the most frequently used words, but rather the term 'project'.

National archives' lines of action or priorities are also listed under different headings, as is often the case in planning terminology (Marco 1996a, b). The word 'strategy' occurs in most, however, either in the plural or as an adjective for nouns or noun phrases such as goal, objective, lines of action, pillars or priorities. France's plan, named 'guidelines', constitutes an exception to that rule.

The plans themselves, all in effect and underway, have diverse durations. Three years is the most common duration (Brazil, Canada, Chile, Finland, France and Peru) followed by 4 years (Australia, Costa Rica, Dominican Republic, New Zealand, Switzerland, United Kingdom and USA). The Colombian, Irish and Macedonian plans are effective for 2 years. The window is particularly wide in Indonesia and Puerto Rico: 20 years. The Puerto Rican plan, however, specifies no issue or approval date. Plan validity is the longest in New Zealand, where the target year is 2057, although 4-year objectives are also defined in its 'Archives 2057 Strategy'. As in the business world, environmental uncertainties and constant change determine the prevalence of 2-, 3- or 4-year plans, while no 5-year plans are in place, despite the prototypical status of that timing for strategic planning (Pacios 2004). The earliest start date, 2016, is defined by Dominican Republic and Switzerland and the latest end date, 2057, by New Zealand, although the most frequent end date is 2020 (shared by five archives).

Plan position on archive websites varies and is found under links on the institution and its purpose entitled 'About us', 'Who we are', 'Get to know us', 'What we do' or 'Institution'. As in national libraries (Pacios and Martínez-Cardama 2019), one of the most frequently used headings is 'About us'. Other less intuitive labels include terms such as 'Publications' or 'Access to information'. The word 'Transparency', another epithet for the link to some plans, is indicative of the desire to enhance the visibility of these documents as a first step towards institutional 


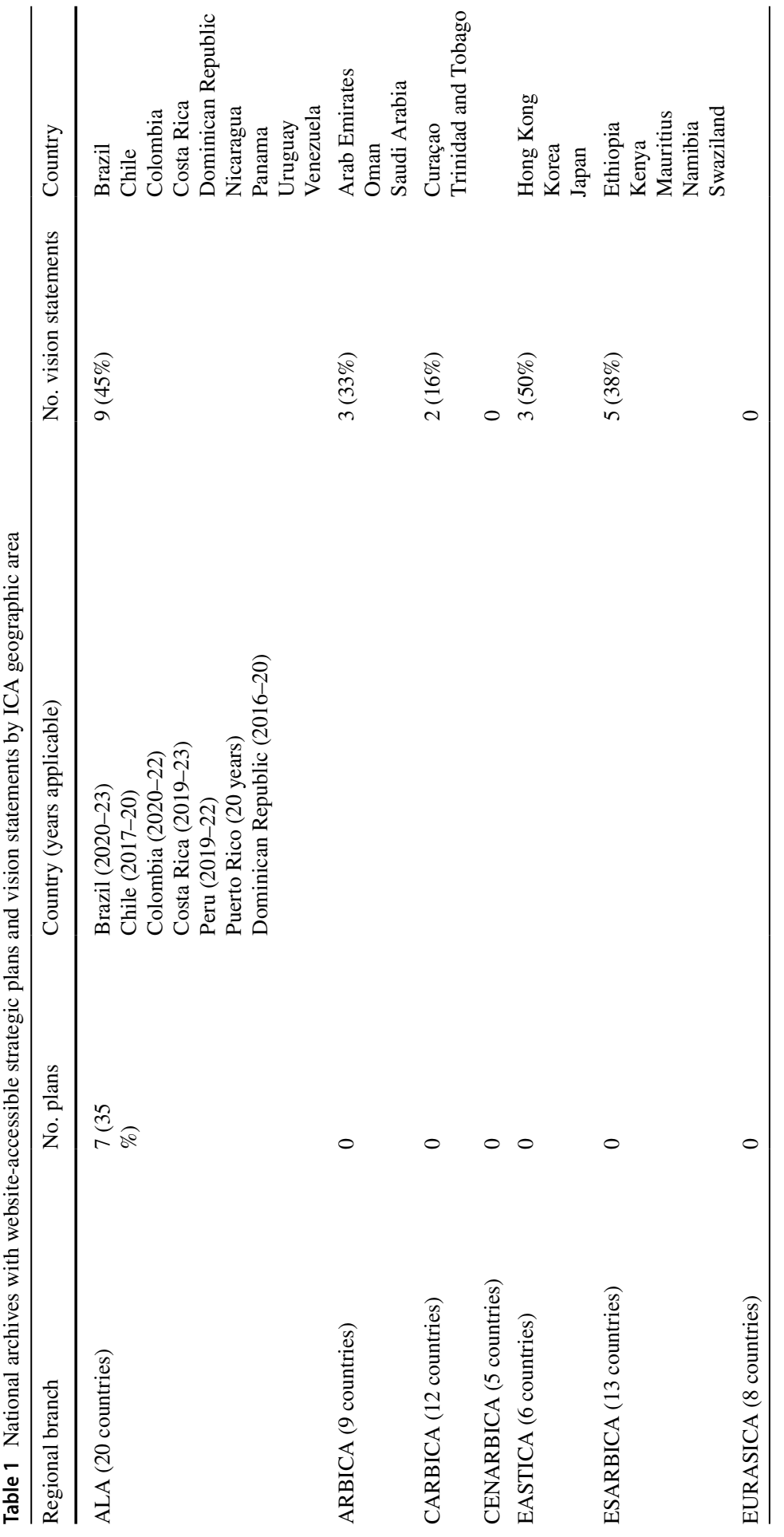




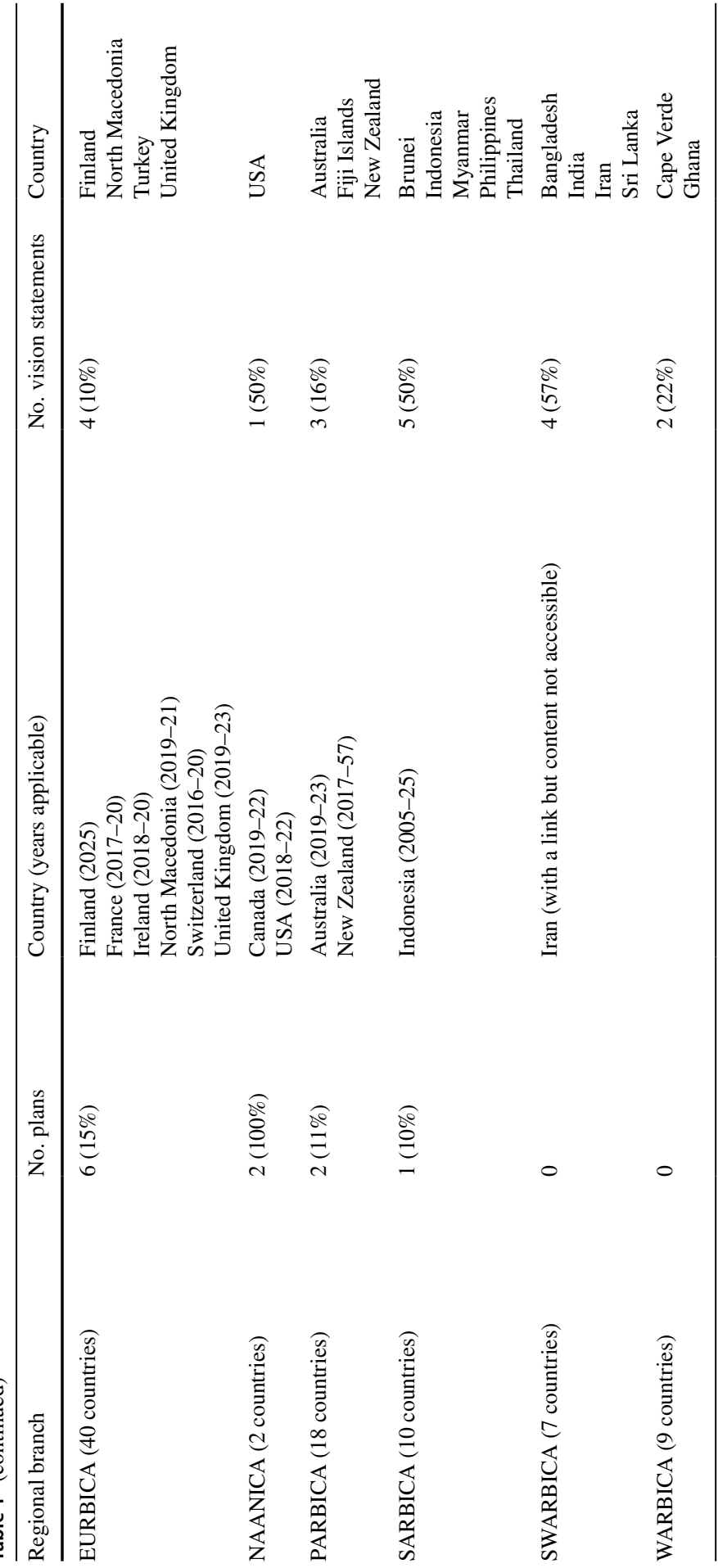




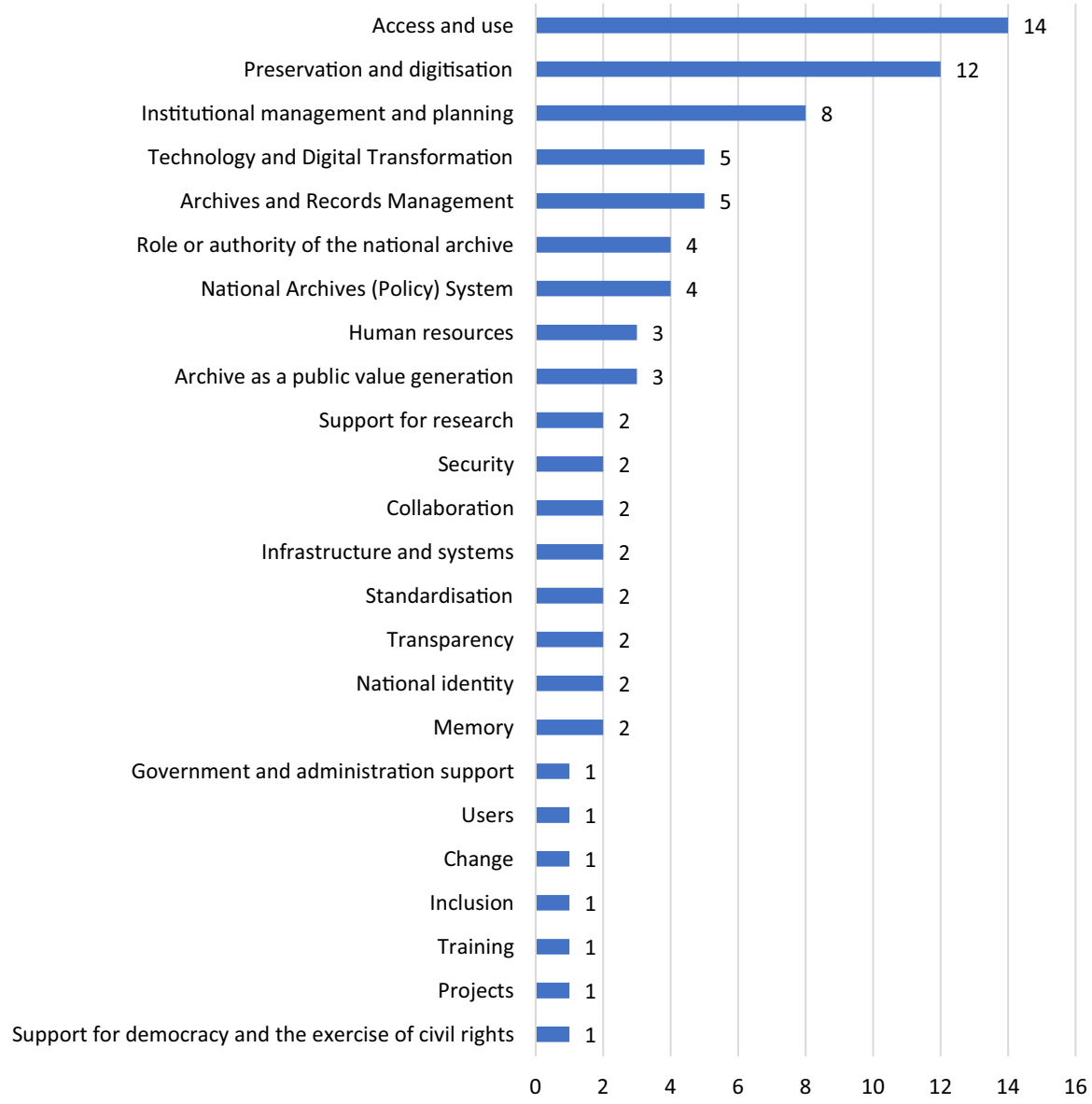

Fig. 1 Priority lines of action extracted from the 18 strategic plans located on national archive websites

transparency (Flyverbom 2016). Surprisingly, the Iran website, while including the link, voids access to plan content.

Another item of interest for the dissemination of strategic plans, given that they are national documents, is their availability in other languages, English in particular. Translating these documents would favour inter-archival benchmarking as well as comparative analysis. Finland and Switzerland are the only two non-English-speaking countries to furnish an English language version of their plans, however. For the present study, the plans available only in languages in which the authors are not proficient were machine translated with AI-enabled tools and multi-language dictionaries.

The subject areas identified in the analysis of the most common lines of action or priorities are discussed as follows.

The four areas carrying the greatest weight include the following. 
Access and use (14). The two most prominent categories are the two associated with the purposes traditionally served by archives, namely to ensure access to and preserve records, respectively, listed by 14 and 12 institutions as priorities. The wording of those intentions varies, from very general notions around guaranteeing citizen access (Peru and Costa Rica) to more specific approaches, such as adopted by the Brazilian national archive, where the idea is explicitly linked to government records. Other archives, such as the Chilean and Dominican institutions, cite conceits such as 'democratising' access to information as an item in their strategies. Other considerations include improved visibility (Irish national archive) and defining new uses for the space available (France).

Collection preservation and digitisation (12). The word digitisation is explicitly listed as a strategy in the French, North Macedonian and Puerto Rican national archives' plans. Overall, preservation, digitisation and subsequent access and use are items included in nearly all the plans analysed. Despite their status as traditional pursuits for these institutions, they continue to be included as plan priorities either in connection with expanding digital collections, establishing more mechanisms for accessing the physical collection, or with improving user query experience. Mention should also be made of the inclusion in archives' plans of their view of the prospects for preserving born-digital collections. The Australian archive, for instance, makes specific reference to its 'Digital Continuity' plan for managing information generated digitally from the outset. Under its Digital Transition Policy, records created digitally after 2015 (i.e. since early 2016) must be kept in digital form. The aim, as set out in the country's Digital Continuity 2020 Policy, is to advance the digital information agenda, improve government efficiency and support e-government and the digital economy beyond 2015. Switzerland's strategic plan prioritises digital archiving in the introduction to the text itself, albeit more from the perspective of access than from process. The archives in question express concern about long-term conservation, while offering consultancy services that would enable third parties to benefit from their experience and infrastructures.

Institutional management and planning (8). The third-ranking concern revolves around strategies geared to improving archives' in-house management and planning. All the archives specifying that engagement are ALA (Asociación Latinoamericana de Archivos, ICA's Latin American branch) members. The idea is broached variously, from inclusion as an effective means for affording the archive a more prominent role, such as in the Chilean archive, to allusions to planning techniques for ongoing improvement in the Colombian document or direct reference to strengthening policy and management competence by the Puerto Rican national archive.

Technology and digital transformation (5) also carries considerable weight in strategic plans. Items range from an infrastructural role in the Dominican Republic and North Macedonia, involving investment in 'technological resources' and 'information technologies', to a leadership position in connection with archive digitisation. The latter item is found in the Colombian as well as the Finnish and Australian 
plans, which pursue a lead role in the provision of digital services and the digital environment.

That is followed in prominence by subjects that reinforce the national archive's authority as the body that guides the country's archival policy and its lead role in the national archive network. With the exception of Indonesia, all the archives with strategies in those categories are Latin American, i.e. ALA members. The inference is regional sensitivity to strengthening the national archive as the authority and guide for a national archive system, entrusted with furthering the country's archival culture.

The Dominican, Finnish and US archives explicitly define human resources as one of the keys to their strategy, the first and last also stressing training and career opportunities for their employees. In the Finnish plan, in contrast, staff members are viewed as an asset from whose 'experience' the organisation draws to reach longterm goals.

One innovative approach to strategy, the archive's role in generating added value, is present in the Colombian, UK and US archives' plans, although the perspective varies. Whereas in Colombia, it is addressed as a goal pursued after redesigning its service model; in the other two countries, it is related to developing new business practices for more efficient access to information. The British archive actually calls this strategy 'The entrepreneurial archive', in clear allusion to its commercial potential.

The following eight categories, Memory, National identity, Transparency, Standardisation, Infrastructure and systems, Collaboration, Security and Support for research are each mentioned as priorities by two archives. The items on historic memory and national identity are consistently found together in the strategies defined by the Chilean and Indonesian archives. In the Canadian and French plans, the two citing it as a priority, collaboration is viewed as an opportunity to partner with other bodies for enhanced dissemination of and access to the collection, albeit within but not outside national boundaries.

The analysis of the subjects included in national archives' strategies prompted a review to determine convergent items in the plans of archives affiliated with a given same ICA branch. The limitations of this survey, conditioned by the short number of plans identified in the chosen universe and the concomitant difficulty in extrapolating the findings internationally, are readily acknowledged. Nonetheless, this exercise was deemed valid for detecting shared lines of action indicative of sensitivities to which greater importance is attached in some regions than others. Table 2 lists the strategies most frequently found in the ICA regions where plans were identified.

\section{Vision statements}

Unlike plans, vision statements are frequently found on national archives' websites around the world. The 41 statements identified are discussed below. The ICA regional branch with the largest number is the ALA (Asociación Latinoamericana de Archivos), with nine. In all the other regions except EASTICA and CENARBICA, at least one national archive publishes its vision statement on 
Table 2 Strategies most frequently identified by ICA region

\begin{tabular}{ll}
\hline ICA regional branch & Strategic categories most frequently cited and number \\
\hline ALA (7 countries) & Preservation and digitisation (7) \\
& Institutional management and planning (7) \\
& Access and use (6) \\
& National archive system (policy) (4) \\
EURBICA (6 countries) & Preservation and digitisation (3) \\
& Technology and analogue to digital conversion (2) \\
& Archive and records management (2) \\
NAANICA ( 2 countries) & Access and use (2) \\
PARBICA ( 2 countries) & Access and use (2) \\
SARBICA ( 1 country) & Access and use (2)
\end{tabular}

its site (Appendix 1). Content analysis detected 69 keywords, 35 of which appear in more than one statement (see graph in Fig. 2).

The most common trends in terms of national archives' aspirations as expressed in their vision statements and number of occurrences are discussed below.

Preservation (13). This trend also heads the subject category list, indisputably because it is the primary aspiration of any national archive. Preservation and conservation are frequently found in conjunction with terms such as memory (nine mentions), heritage (eight) and history (three), for preservation is usually associated with an ultimate purpose: to ensure the endurance of a country's collective memory and written heritage. That is attested to in some national archives, as in Namibia, whose vision statement cites the construction and preservation of collections that reflect the history and aspirations of the Namibian people as one of its aims. New Zealand's lengthy document, in turn, refers to its role as an institution entrusted with preserving the people's history, as well as their personal histories and rights. The national archives of Hong Kong and Cape Verde relate their vision to their ultimate purpose, to preserve the written heritage in a digital environment. In India, the archive's endeavour to preserve the country's heritage is set against the backdrop of the dissemination of national pride.

Archive and records management (10). This second-ranking category covers ideas expressed literally in a number of ways: archival management, information management, records management, document management.

Many of these statements, such as Brazil's for instance, are geared to reinforcing the national archive's key role in establishing records management policies. Some statements (Turkey) highlight its 'centralising' effects for unifying the country's records management while others (Venezuela) stress the responsibility for archives modernisation. Yet others refer to the support afforded government in archive and records management. The Nicaraguan vision statement, for instance, cites its contribution to governmental administration. New Zealand's statement accentuates its 


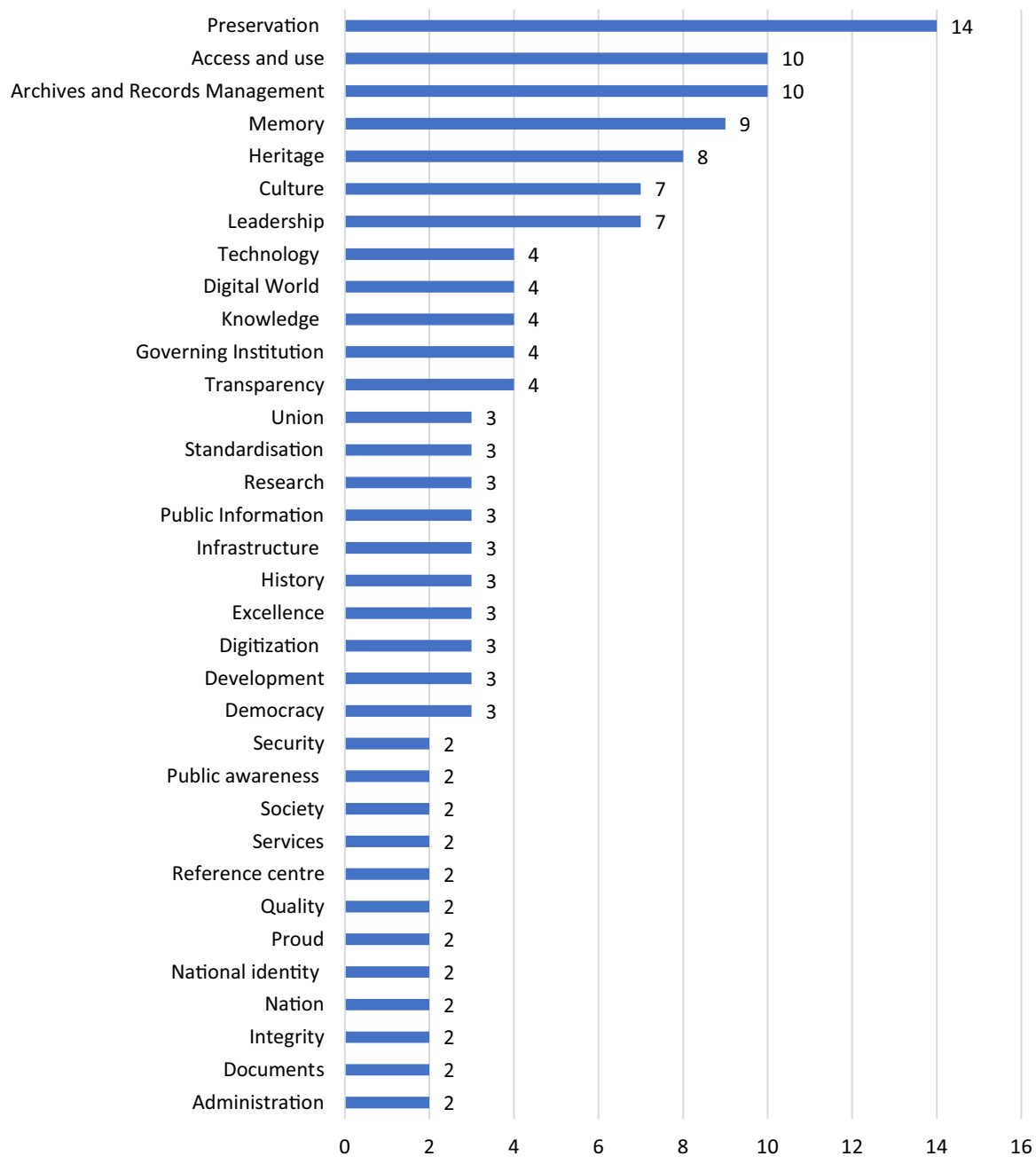

Fig. 2 Most frequent keywords in the 41 vision statements published by ICA national archive members

national archive's independent, reliable and efficient administrative records management for all levels of government.

Access and use (9). Standing in third place, this item attests to an archive's determination to guarantee citizen access to all its collections. Nonetheless, the formula chosen to emphasise the importance of archival access varies. Access is usually understood as the basis for generating memory and collective identity, such as in Chile where the national archive guarantees 'access to information of public interest to contribute to building citizenship and memory'. Association with national identity is found under different headings, such as in the Fiji Island national archive's statement, where it is linked to national unity (three occurrences). Free and democratic 
society building is another idea associated with access, in this case by the Curaçao national archive.

Some archives use other conceits to define access, geared to a broader vision of collections, citing not only documents but data. The Finnish national archive's statement cites the open access to data, while the US archive's document guarantees access to records, data and context.

The word digitisation, with three occurrences (Cape Verde, Finland, Japan), is related to both access and preservation.

Memory (9), Heritage (8) and Culture (7) are terms associated with national archive's vision statements with the potential utility inherent in citizen access to their collections. In today's globalised world, the heritage and collective memory protected are mirrored in a country's culture. These recurrent ideas relate to national archives' role in contributing to their country's cultural development through both the information in their collections and the activities conducted. Some archives consequently define themselves as one of their country's cultural institutions or even as research institutions (Uruguay). Support for the research conducted by key scientific institutions is cited in three of the statements analysed.

Other statements, such as Trinidad and Tobago's, refer to archival support for the nation's cultural and intellectual life, while the Nicaraguan national archive claims to participate in the country's cultural development. A different approach is adopted by the Korean and Ethiopian national archives, whose statements mention the intention to create archival culture or information use culture.

Leadership (7). This term embraces the aspiration to be viewed by society and the international archival community as one of the country's leading organisations. The Panamanian national archive's statement, for instance, contends that it is a 'regional leader in national archive management', while Hong Kong's defines the archive as a 'leading archive', an aspiration also cited in Arab Emirate's and Finland's statements. The US national archive, in turn, alludes to its leadership in guiding professionals in digital archival environments.

'Governing institution', a term closely associated with leadership, is cited in four statements to define the archive's position at the head of the national archive network or its supervisory role in the country's archival circles. The fact that all four are ALA (Asociación Latinoamericana de Archivos) member archive (Chile, Costa Rica, Dominican Republic and Venezuela) documents is an indication of regional sensitivity to the need for a genuine archival system.

Other descriptions attempting to reinforce leadership refer to the intention to become a centre of or geared to excellence (explicitly in the Saudi Arabian, Ghanaian and Curaçao statements). Lastly, the term 'national pride' is used by two archives to refer to the aspiration to play a prominent role as an institution.

Knowledge (4). This is another keyword appearing from the perspective of an archive's 'production' through its collections (as in Brazil) and also as support for the creation of a knowledge-based society. 
Digital world (4). In addition to stressing the importance of technological development, archives aspire to a presence in the long-term future 'digital environment'. That online presence is cited in the vision statements published by the Australian, Cape Verde, Hong Kong and US national archives.

Transparency (4). The four statements including this item view it from three distinct perspectives: either as a guarantor of institutional transparency (Namibia), as a transparent body in itself (Colombia, Costa Rica) and as transparency in the context of information management (Venezuela). The role as guarantor of the country's transparency is likewise related to the good governance cited in the Namibian and Philippine statements.

Other associated keywords include definition of and compliance with standardised procedures; importance attached to infrastructure, design and space remodelling; and support for technology.

National archives' public role and support for democracy are attested to by the frequency of terms such as public information (3), democracy (3) and society (2). The vision of archives as institutions furthering national union is found in the statements published by the Fiji Island, Curaçao and Indonesian archives. Other expressions favouring national archives' societal role include national identity (2) and development (2). Archives are seen as a tool that may be used in the future to improve society or rebuild a country around its collective memory.

The word cloud in Fig. 3, constructed by weighting the terms used in keeping with their frequency in the sample, reveals the predominance of expressions such as preservation, access and use, management, culture and heritage.

\section{Discussion}

An analysis of the findings in connection with plans and statements provided answers to the research questions posed.

The paucity of plans detected answers R.Q.1 on the importance attached to strategic planning by national archives. That strategic plans are present on only $11.3 \%$ of the 159 websites reviewed stands as evidence that formulation and dissemination of these documents is not yet standard practice in national archives. As only the plans that were publicly accessible were assessed here, the tool may be in place in some of the archives omitted but not uploaded to their websites. This study is an attempt to highlight the importance of public dissemination of these documents as a guide for inter-archive benchmarking, which would also favour cooperation and partnering and contribute to organisational transparency. In light of the findings, the need for archives to implement long-term plans and strategies must be emphasised. Research on planning, initiatives and programmes in the realm of archives is still very limited.

Paradoxically, a substantially larger percentage $(25.78 \%)$ of websites include vision statements. Archival preference to publish vision statements over strategic plans may be attributed to the longer term validity of the former, not to mention their readier formulation. Whereas vision statements depict the organisation's future situation in general, strategic plans involve thoughtful consideration of the course to 


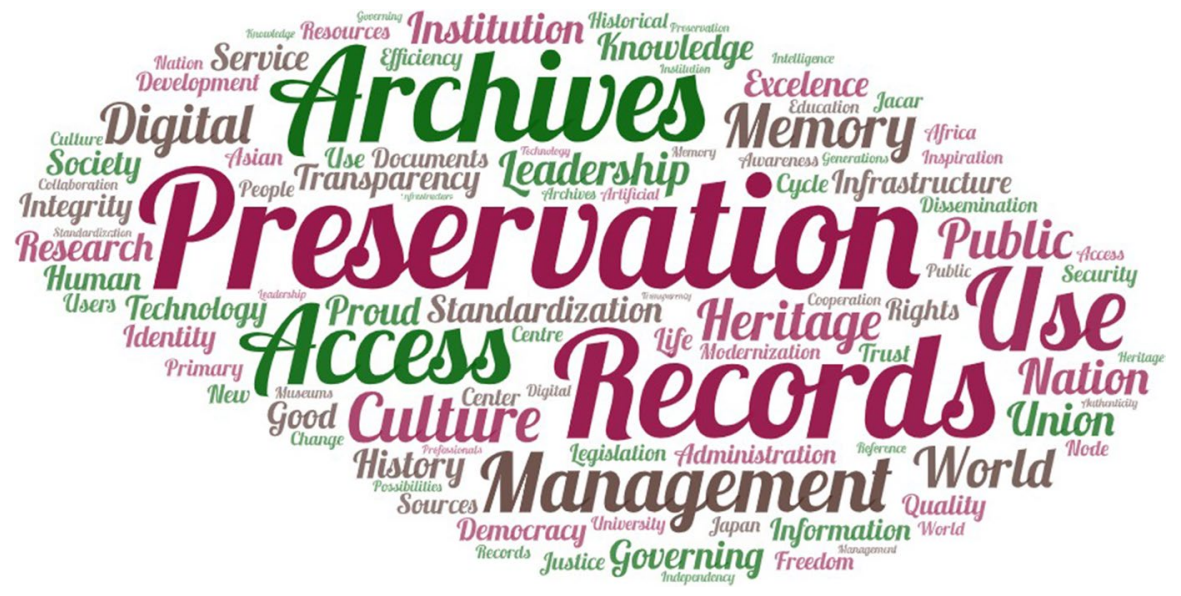

Fig. 3 Word cloud with keywords appearing in vision statements

be followed by the institution in a specific timeframe and the resources required to reach the objectives defined. Future research might explore the actual reasons for the omission of strategies in archival planning or their absence on websites, inasmuch as the respective documents are an essential tool for enhancing the transparency of archives the world over.

Despite the imbalance between the number of strategic plans and the number of vision statements, their joint analysis may suggest a reply to R.Q.2. For instance, archives' strategies tend to match the keywords most often repeated in vision statements. Items such as guaranteeing access to records and collections, their preservation and digitisation, along with the establishment of record and document management mechanisms and policies are present in both the plans and the statements issued by State-run archives.

Another significant finding is that many plans and statements aspire to strengthen the national archive's role in its community and state archive management. The creation or enhancement of a national archive network with the national archive as the head or governing institution is another common concern set out in both plans and visions. Frequent mentions of leadership or excellence with the national archive as a benchmark are also present. Such interest in role enhancement connects with case studies published on the assessment of actual awareness raising among African countries such as Nigeria (Onuoha 2013), Ghana (Out and Asante 2015) and Tanzania (Chami 2017), and in the International Council on Archives' East and Southern African Regional Branch (ESARBICA) (Venson et al. 2014). Curiously, the specialised literature on national archives seems to focus on eastern and southern Africa, a region for which not a single strategic plan was found in this study. Academic papers can therefore be said to detect a need to improve and revitalise those archives.

An analysis of the public disclosure of vision statements therefore reveals the prominence and influence of national archives as State bodies with a substantial say in the construction of countries' history. Karabinos (2018) contends that such 
influence is revealed by their position on access to and selection and description of their collections. The underlying principles determine the propagation of certain historic narratives over others. That author notes that national archives' statements on national memory, collective memory, national identity or heritage and its public accessibility inform archives' influence and importance in each country. Their role is consequently studied in the construction of national narratives, either in the legitimation and construction of nation-states in Europe (Berger 2013) or post-colonial narratives in the case of the Malaysian and Singaporean national archives (Karabinos 2018).

R.Q.3 on whether similarities or differences can be identified between national archives' strategies depending on the regional ICA branch with which they are affiliated cannot be readily answered due to the low number of plans found. Nonetheless, a close analysis of Table 2 reveals that certain issues are shared across the globe. Access and use occupy a place of prominence in three of the four regions studied. Guaranteeing mechanisms that make collections and records available and democratise access may be said to be an ongoing priority, internationally. While dependent upon the degree of country development, the pursuit of formulas to improve user access and experience or to capitalise optimally on collections are enduring aspirations in all archives.

Of the regions analysed, ALA is the one most predominant and where concurrence in the strategies analysed is greatest. Outside of access, other prevalent items include preservation and digitisation (7), improvement of management and planning tools (7) and the national archive's role in the country's archive network (4). Given the regional scale implications, attention is drawn to the inclusion of the national archive's role in such networks in six of the seven ALA members' plans. Their creation and nationwide coordination by a strong national archive therefore constitutes one of the primary future goals sought by such archives.

Plans in place in the other regions analysed differ more widely, sharing fewer strategies. In EURBICA, concurrence in such strategies is not common: the sole match, preservation and digitisation, is present in only three of the six national archives represented. Similarly, in NAANICA and PARBICA, access and use are the only shared item on strategic plans. SARBICA has only one representative, Indonesia, whose plan highlights the need to strengthen the national archive and its areas of competence.

\section{Conclusions}

This study, a first-time analysis of the strategic plans and vision statements of 159 national archives around the world, identifies significant particulars about these institutions' priorities but also about issues such as shortcomings in their digital presence. The search for the respective websites was conditioned by the disappearance of some and the non-currency of others, all of which translated into substantial differences relative to the international directory published by Franks and Bernier in 2018. Website ephemerality, together with the general absence of 
research on national archives in the literature, gives reason to set scientific sights on such archives.

Very few national archives disclose what they aim to do in the future, or only a few publish such information on their websites. No support was found for the idea that planning is a tool used by these institutions. Not a single plan was located, for instance, in CENARBICA, WARBICA, ESARBICA, EURASICA, EASTICA, CARBICA or ARBICA.

Any comparison of national archives' strategies is logically conditioned by the scant online presence of such documents and the archival development of the respective country or region. Authors such as Friedrich (2018) describe the difficulty in conducting global scale research due to discrepancies over the definition of the term itself, archive, and the lack of consensus around the nineteenth century Eurocentric vision of modern archives as State-supportive institutions. Hence, the perspective adopted here to base searches on ICA regional branches to assess possible convergent sensitivities in regions with a tradition of archiving records or similar strategies. ALA was found to be the most active region and the one where more plans address the same issues.

The priorities and aspirations most commonly detected, preservation and digitisation, are explicable because they are based on the benefits to be derived by any archive, essentially as mechanisms to ensure the dissemination of the cultural heritage materials contained in their collections. Specialists and institutions have spotlighted the reasons that motivate digitisation (IFLA 2002; McKay 2003), particularly in developing countries (Eze Asogwa 2011). Access, in turn, another priority repeated across different archives that is severely hindered if records are not digitised, indisputably impacts the use of archival services. Indeed, 'digitisation transforms a substantially private service (rival and excludible) into a collective one available to anyone at the same time' (Guccio et al. 2016, p.59).

That is indicative of the utility of digitisation for, and its impact on, archive efficiency. Although digitisation is a priority for many archives, its application may differ due to the specific situation created by the digital divide in some countries, a problem that calls for major public investment in infrastructures, education and services. Although this issue has been (Voutssas 2012) and continues to be (Barquero 2019) a matter of constant concern, actual circumstances have yet to be fully ascertained. The Asociación Latinoamericana de Archivos has created a working group on the management and preservation of digital formats to share experience in the implementation of similar projects. That will provide a first snapshot of the regional state of the art in this regard. Similar initiatives in other ICA regions would surely afford insight into the present situation of and future agenda for national archives.

Future research should seek to identify the major areas on which digital archiving policies are focused, together with the access to and use and reuse of digital objects. The presence or otherwise of a policy for withdrawal of digital materials should also be determined. A third research target would be to monitor the services envisioned in some strategic plans, such as the digital archiving consultancy and support offered in Switzerland. Digital transformation is, then, ushering in a very fruitful period for national archives. 
This study attests to the importance of strategic plans and vision statements as elements contributing to national archive transparency, in addition to constituting benchmark behaviour for any of a country's other archives. They should be deemed to form part of these institutions' public disclosure policy and as such be routinely posted on their websites further to the transparency legislation in place, of which Spain's 2013 Transparency Act is one of any number of examples. Otherwise, citizen access to institutional priorities and lines of action cannot be ensured. Despite the low number of national archives posting these documents and their uneven distribution across ICA's membership, the analysis conducted of their content identified certain major issues that indicate where they are headed. Archives are urged to extend their plans upon expiration and systematically review their vision statements over time to afford the general public cognizance of these documents and of any change in institutional priorities and guidelines.

\section{Appendix 1}

See Table 3. 


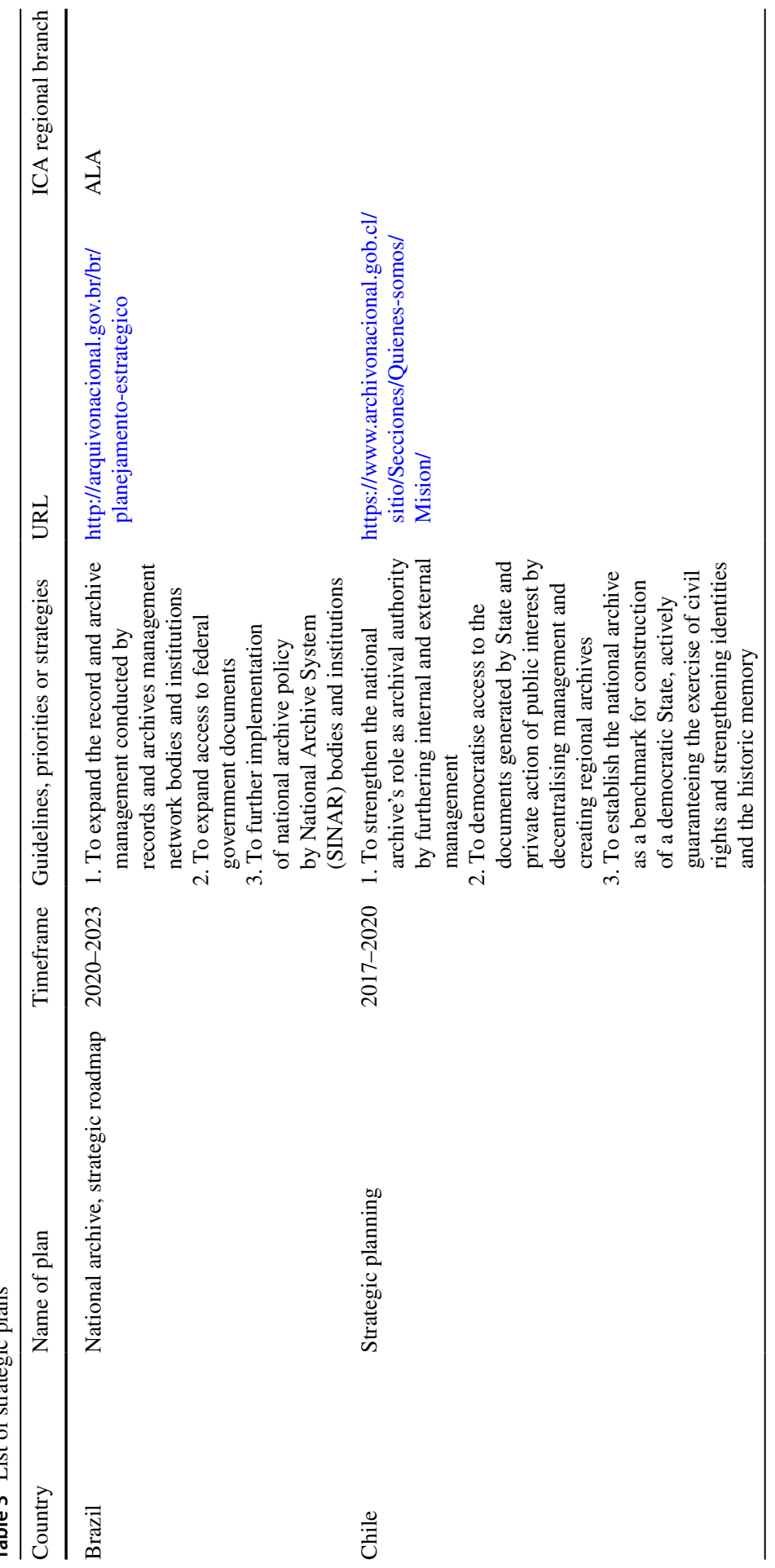




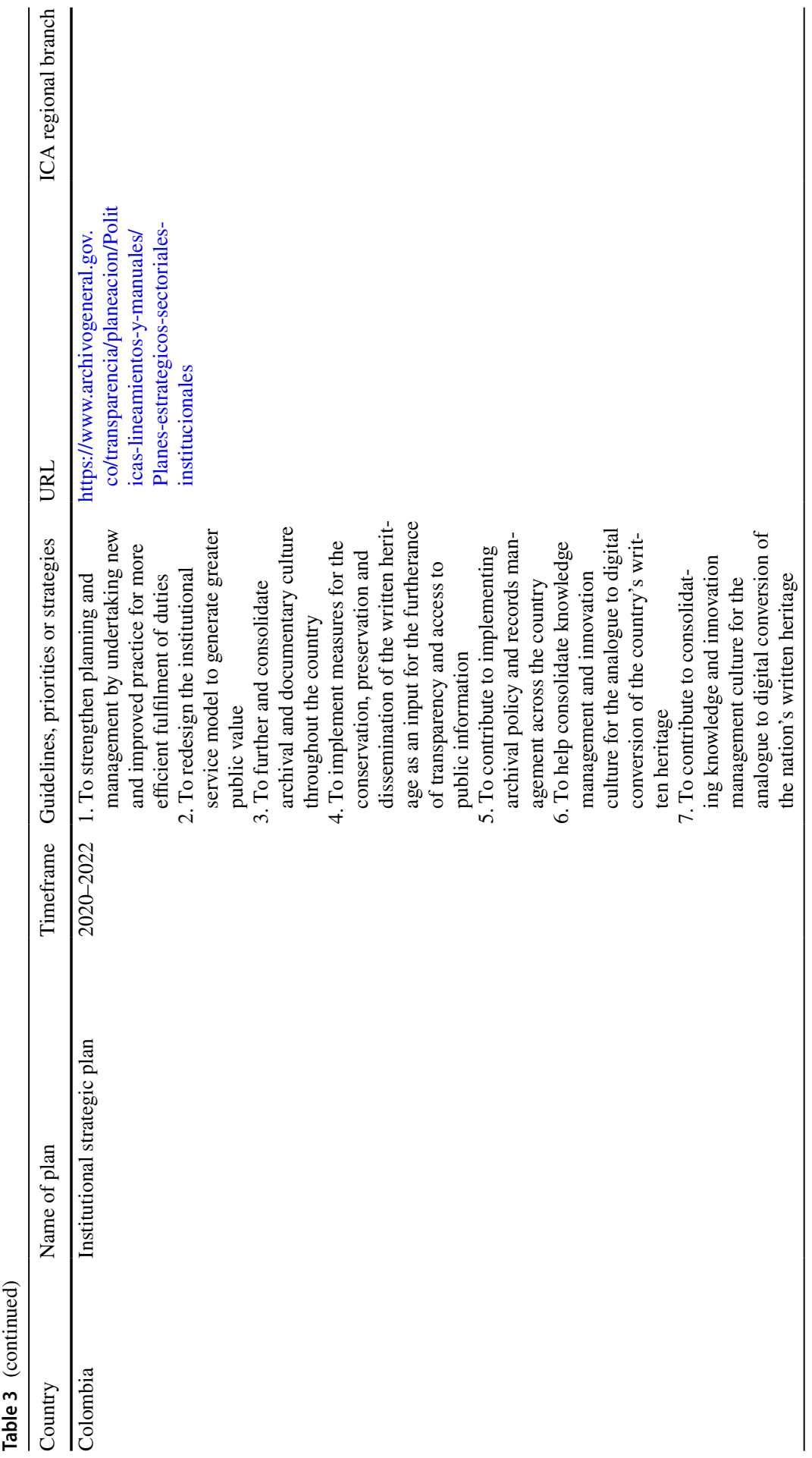




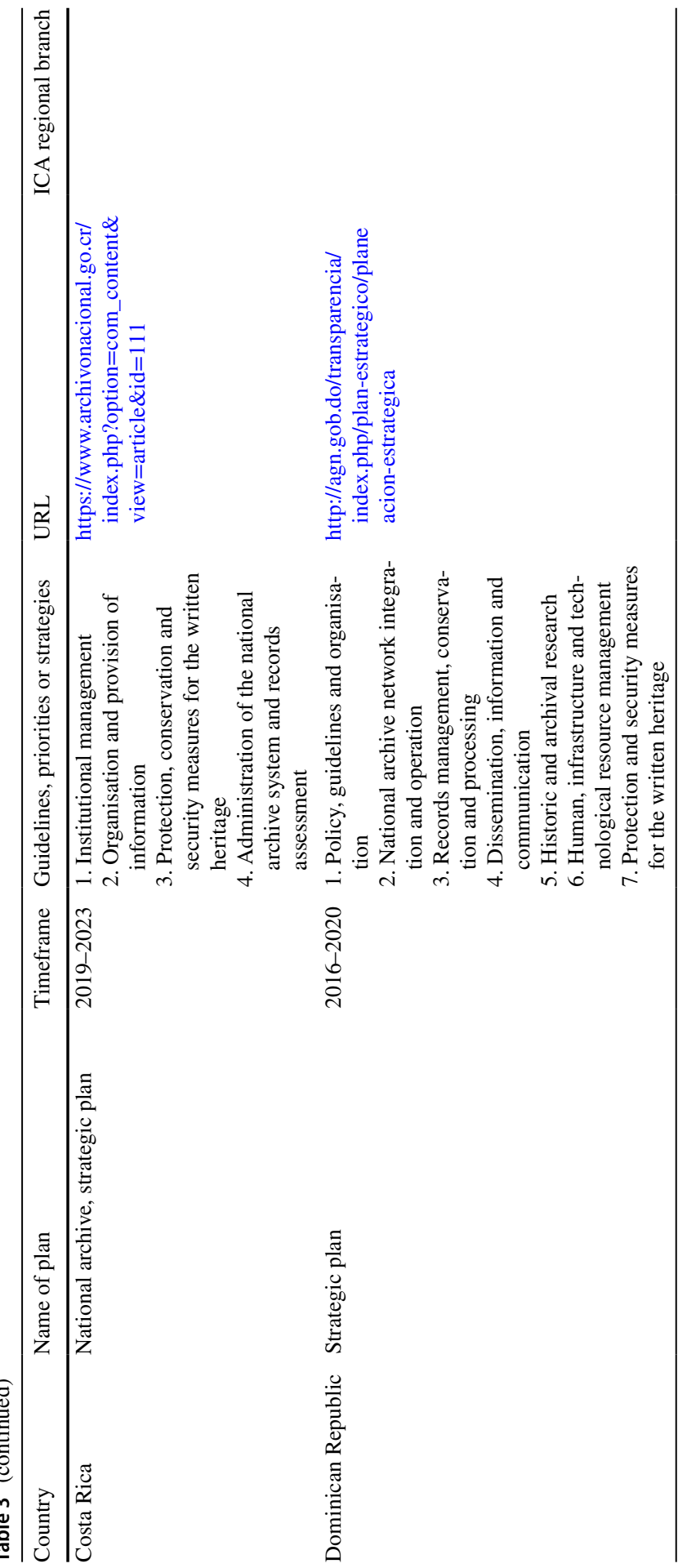




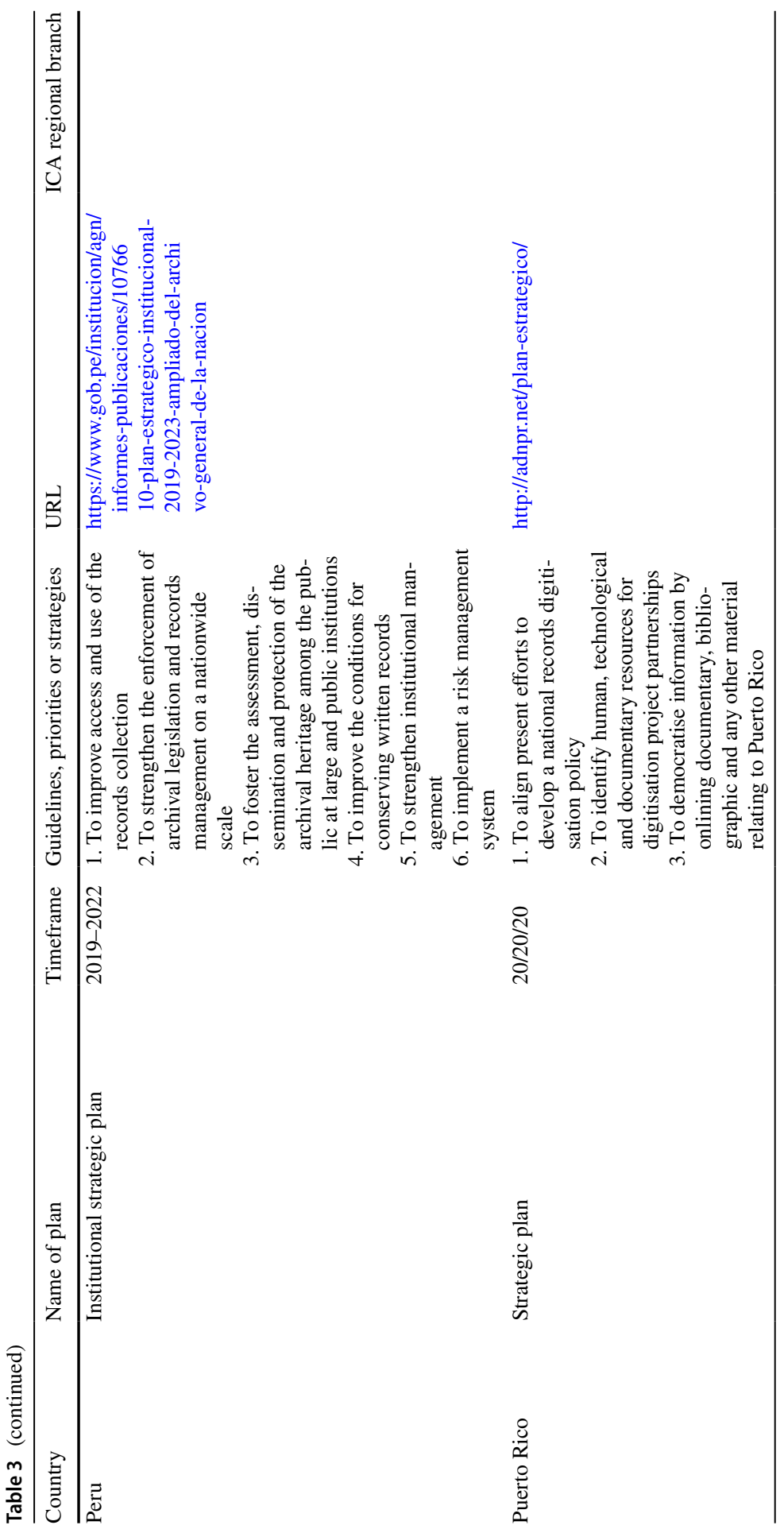




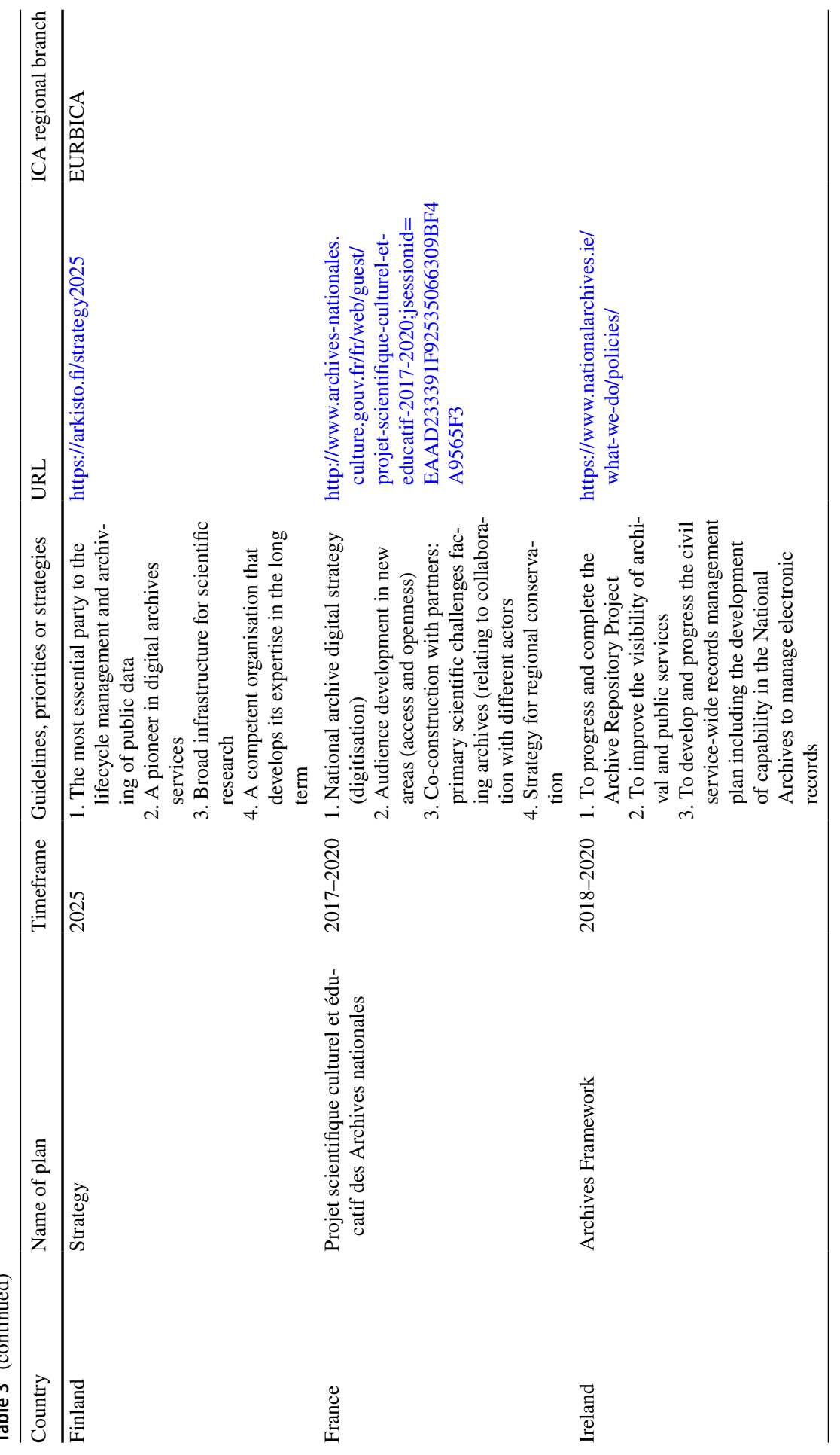




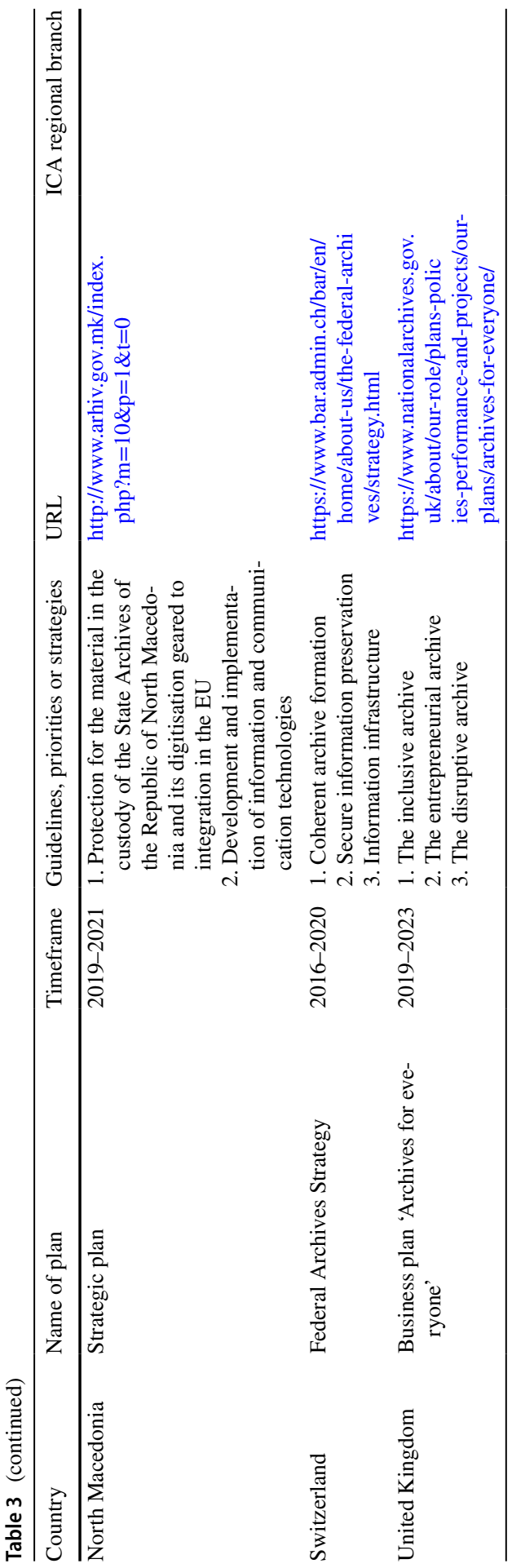




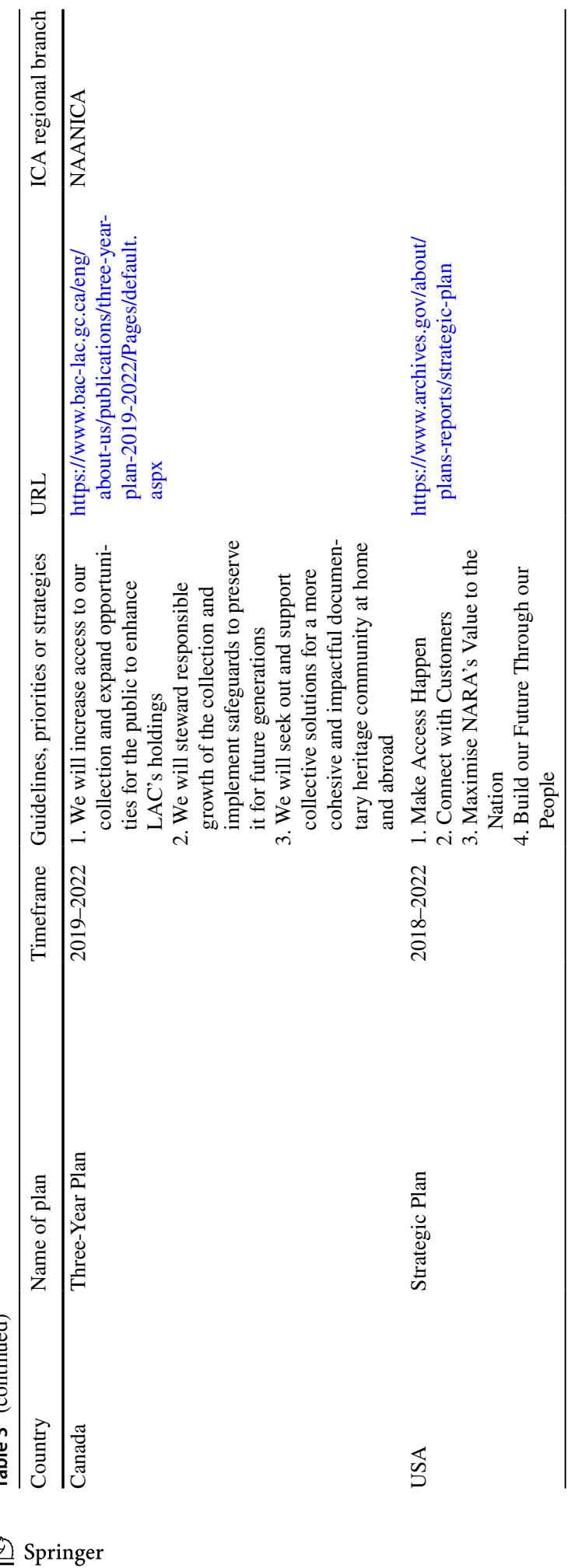




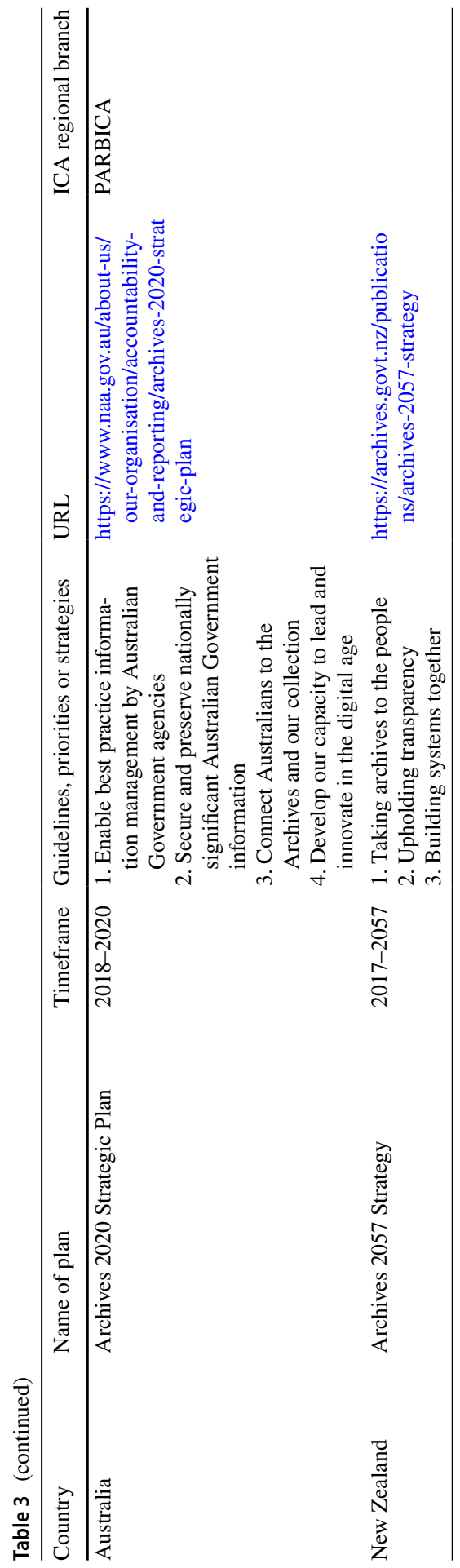




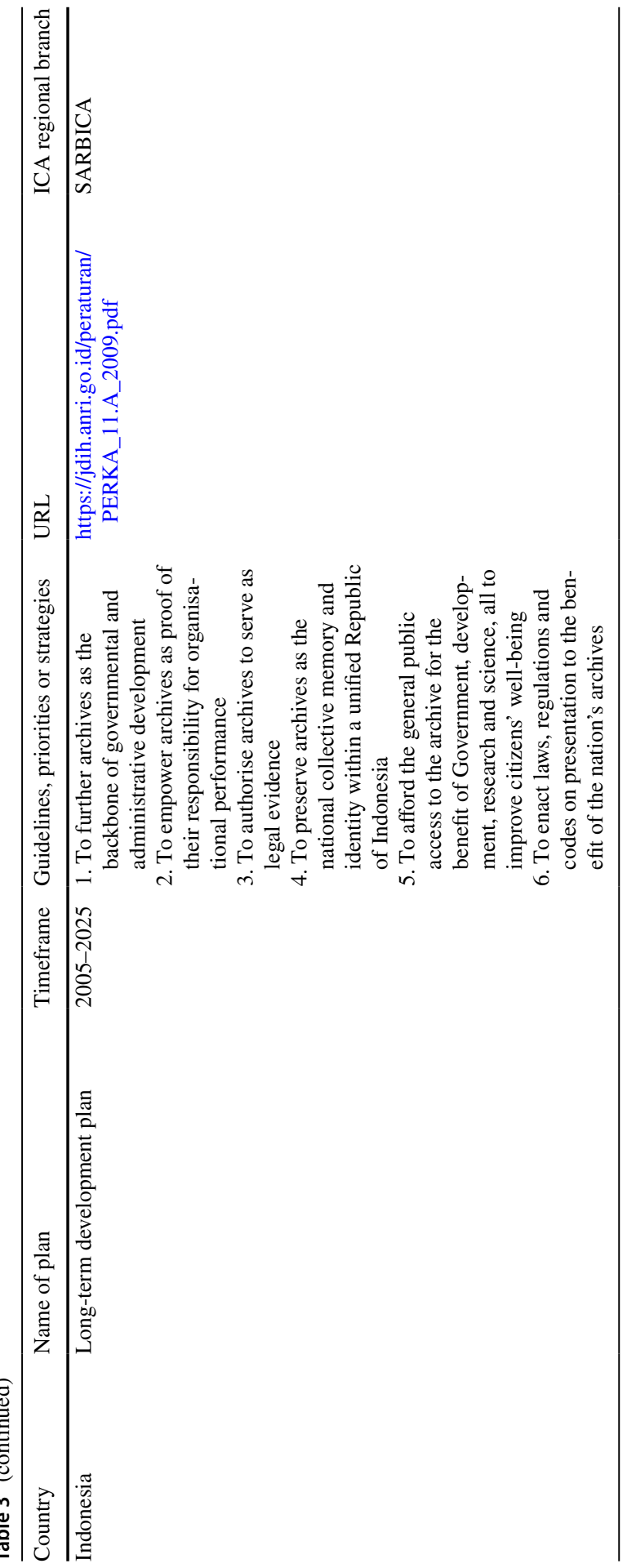




\section{Appendix 2}

\section{See Table 4.}

Table 4 List of vision statements

\begin{tabular}{|c|c|c|c|c|}
\hline Archive & Vision statement & $\begin{array}{l}\text { Time } \\
\text { limit }\end{array}$ & URL & ICA region \\
\hline Brazil & $\begin{array}{l}\text { To consolidate strategic performance in } \\
\text { federal government as a benchmark } \\
\text { for records management, custody and } \\
\text { preservation and archival knowledge } \\
\text { production }\end{array}$ & No & $\begin{array}{l}\text { http://www.arqui } \\
\text { vonacional.gov. } \\
\text { br/images/Mapa_ } \\
\text { estrategico_ } \\
\text { 2020_2023_final_ } \\
\text { ascom_1.jpg }\end{array}$ & ALA \\
\hline Chile & $\begin{array}{l}\text { To define standards guaranteeing access } \\
\text { to public and private information of } \\
\text { public interest, contribute to identity, } \\
\text { citizenship and memory building } \\
\text { on the national and regional scales. } \\
\text { That calls for a legal, regulatory and } \\
\text { procedural structure, modern hardware } \\
\text { and software infrastructure and highly } \\
\text { qualified personnel }\end{array}$ & No & $\begin{array}{l}\text { https://www.archi } \\
\text { vonacional.gob. } \\
\text { cl/616/w3-prope } \\
\text { rtyvalue-47688. } \\
\text { html?_nored } \\
\text { irect=1 }\end{array}$ & \\
\hline Colombia & $\begin{array}{l}\text { In } 2022 \text { the nation's General Archives } \\
\text { will be acknowledged as the head } \\
\text { nationwide archival institution for } \\
\text { modernising and strengthening the } \\
\text { country's written heritage via analogue } \\
\text { to digital conversion for suitable infor- } \\
\text { mation processing and management, to } \\
\text { preserve the value and significance of } \\
\text { such information while safeguarding its } \\
\text { integrity, security and transparency }\end{array}$ & $\begin{array}{l}\text { Yes } \\
\quad(2022)\end{array}$ & $\begin{array}{l}\text { https://www.archi } \\
\text { vogeneral.gov. } \\
\text { co/Conozcanos/ } \\
\text { mision-vision }\end{array}$ & \\
\hline Costa Rica & $\begin{array}{l}\text { The Costa Rican National Archive will } \\
\text { exercise its supervisory role over the } \\
\text { national archive network and offer } \\
\text { Costa Rican citizens new and better } \\
\text { services, growing the heritage with } \\
\text { new collections through retrieval, } \\
\text { organisation, conservation, provision } \\
\text { and dissemination. These challenges } \\
\text { will be assumed by improving hard- } \\
\text { and software infrastructures, the legal } \\
\text { structure adapted to today's needs and } \\
\text { highly qualified human resources com- } \\
\text { mitted to efficiency and transparency } \\
\text { and geared to customer service }\end{array}$ & No & $\begin{array}{l}\text { https://si.cultura.cr/ } \\
\text { infraestructura/ } \\
\text { archivo-nacio } \\
\text { nal-de-costa-rica. } \\
\text { html\#: :text= } \\
\text { Visi\%C3\%B3n,\% } \\
\text { 2C\%20conserva } \\
\text { ci\%C3\%B3n\% } \\
\text { 2C\%20facilitaci\% } \\
\text { C3\%B3n\%20y\% } \\
\text { 20divulgaci\%C3\% } \\
\text { B3n }\end{array}$ & \\
\hline $\begin{array}{c}\text { Dominican } \\
\text { Republic }\end{array}$ & $\begin{array}{l}\text { To be a highly competent institution in } \\
\text { archival operationality and quality, } \\
\text { contributing to its consolidation as a } \\
\text { governing and advisory organisation } \\
\text { for the management, development } \\
\text { and optimisation of the documentary } \\
\text { services provided by the Dominican } \\
\text { Republic's national archive network }\end{array}$ & No & $\begin{array}{l}\text { http://agn.gob.do/ } \\
\text { index.php/sobre- } \\
\text { nosotros/quien } \\
\text { es-somos }\end{array}$ & \\
\hline
\end{tabular}


Table 4 (Continued)

\begin{tabular}{|c|c|c|c|c|}
\hline Archive & Vision statement & $\begin{array}{l}\text { Time } \\
\text { limit }\end{array}$ & URL & ICA region \\
\hline Nicaragua & $\begin{array}{l}\text { To shape the nation's written memory } \\
\text { contained in administrative and } \\
\text { historic, public and private archives to } \\
\text { contribute to the efficient management } \\
\text { of State records and citizens' cultural } \\
\text { development by making the primary } \\
\text { sources of information available as part } \\
\text { of their national identity }\end{array}$ & No & $\begin{array}{l}\text { https://www.inc.gob. } \\
\text { ni/bibliotecas-y- } \\
\text { archivos/ }\end{array}$ & \\
\hline Panama & $\begin{array}{l}\text { Regional leader in national archive } \\
\text { management, inspiring Panamanians } \\
\text { to document, come to know and share } \\
\text { their history }\end{array}$ & No & $\begin{array}{l}\text { http://www.archi } \\
\text { vonacional.gob. } \\
\text { pa/?page_id=13 }\end{array}$ & \\
\hline Uruguay & $\begin{array}{l}\text { The nation's General Archives serve the } \\
\text { State, protecting public information } \\
\text { and ensuring its accessibility. Such } \\
\text { documents protect human rights by } \\
\text { ensuring rights and obligations are } \\
\text { documented clearly and precisely. The } \\
\text { General Archives are a cornerstone in a } \\
\text { democratic society, serve the judiciary } \\
\text { (among others) by administering the } \\
\text { judicial records in its collection. It is } \\
\text { also one of the nation's pivotal cultural } \\
\text { institution, conducting research and } \\
\text { safeguarding memory }\end{array}$ & No & $\begin{array}{l}\text { http://www.agn. } \\
\text { gub.uy/ }\end{array}$ & \\
\hline Venezuela & $\begin{array}{l}\text { In 2022, The National Archives of } \\
\text { Venezuela will be recognised as a } \\
\text { leading entity in the modernization } \\
\text { of archives in the national territory } \\
\text { and the strengthening of the country's } \\
\text { documentary heritage, through a digital } \\
\text { transformation that allows an adequate } \\
\text { information management. This will } \\
\text { allow to preserve its value and mean- } \\
\text { ing, trying to safeguard its integrity, } \\
\text { security and transparency }\end{array}$ & $\begin{array}{l}\text { Yes } \\
\quad(2022)\end{array}$ & $\begin{array}{l}\text { https://www.archi } \\
\text { vogeneral.gov. } \\
\text { co/Conozcanos/ } \\
\text { mision-vision }\end{array}$ & \\
\hline $\begin{array}{l}\text { Arab } \\
\text { Emirates }\end{array}$ & $\begin{array}{l}\text { Leadership in providing distinctive } \\
\text { Archival, Documentation \& Research } \\
\text { services }\end{array}$ & No & $\begin{array}{l}\text { https://www.na.ae/ } \\
\text { en/aboutus/visio } \\
\text { nmissionvalues. } \\
\text { aspx }\end{array}$ & ARBICA \\
\hline Oman & $\begin{array}{l}\text { We preserve our antique history to build } \\
\text { a brighter future }\end{array}$ & No & $\begin{array}{l}\text { https://nraa.gov. } \\
\text { om/about-nraa/? } \\
\text { lang=en }\end{array}$ & \\
\hline
\end{tabular}


Table 4 (Continued)

\begin{tabular}{|c|c|c|c|c|}
\hline Archive & Vision statement & $\begin{array}{l}\text { Time } \\
\text { limit }\end{array}$ & URL & ICA region \\
\hline $\begin{array}{l}\text { Saudi } \\
\text { Arabia }\end{array}$ & $\begin{array}{l}\text { To be a centre of excellence at the local, } \\
\text { national and regional levels that con- } \\
\text { tributes in promoting the integration } \\
\text { and partnership with concerned parties, } \\
\text { preserving the University's work docu- } \\
\text { ments, historical documents from the } \\
\text { Eastern Province and surrounding areas } \\
\text { as well as other important documents. } \\
\text { The kinds of documentation may } \\
\text { include records, deeds, manuscripts, } \\
\text { archives, pictures and film. The Centre } \\
\text { will provide access to the Univer- } \\
\text { sity's students and all beneficiaries in } \\
\text { the easiest and most expedient ways } \\
\text { within a professional framework using } \\
\text { advanced mechanisms and techniques }\end{array}$ & No & $\begin{array}{l}\text { https://www.iau. } \\
\text { edu.sa/en/admin } \\
\text { istration/cente } \\
\text { rs/documents- } \\
\text { and-information- } \\
\text { center/about }\end{array}$ & \\
\hline $\begin{array}{l}\text { Trinidad } \\
\text { and } \\
\text { Tobago }\end{array}$ & $\begin{array}{l}\text { The National Archives of Trinidad and } \\
\text { Tobago (NATT) will provide services } \\
\text { that build, maintain, and allow access } \\
\text { to Trinidad and Tobago's records to } \\
\text { sustain a free, open, and democratic } \\
\text { society and to support the cultural and } \\
\text { intellectual life of all citizens of Trini- } \\
\text { dad and Tobago. We will relentlessly } \\
\text { pursue excellence in all our endeavours }\end{array}$ & No & $\begin{array}{l}\text { https://natt.gov.tt/ } \\
\text { node/14 }\end{array}$ & CARBICA \\
\hline Curaçao & $\begin{array}{l}\text { Develop Curaçao National Archives as } \\
\text { a biding force to ensure national unity. } \\
\text { Its objective is to create a modern open } \\
\text { information centre as a pathway to } \\
\text { preserve the memory of the country. } \\
\text { It also contributes to the exercise of } \\
\text { administrative duties and } \\
\text { promoting the historical awareness of the } \\
\text { Country }\end{array}$ & No & $\begin{array}{l}\text { https://www.natio } \\
\text { naalarchief.cw/ } \\
\text { organisatie/missie- } \\
\text { visie-en-doelen }\end{array}$ & \\
\hline $\begin{array}{l}\text { Hong } \\
\text { Kong }\end{array}$ & $\begin{array}{l}\text { To be the leading, most insightful and } \\
\text { resourceful public archives in Hong } \\
\text { Kong that excels in preserving and } \\
\text { promoting the documentary heritage of } \\
\text { our city in the digital era }\end{array}$ & No & $\begin{array}{l}\text { https://www.grs.gov. } \\
\text { hk/en/vision_missi } \\
\text { on_and_values. } \\
\text { html }\end{array}$ & ESASTICA \\
\hline Korea & $\begin{array}{l}\text { Bringing global archival culture to } \\
\text { Korea: } \\
\text { Building foundation to advance archival } \\
\text { administration } \\
\text { Streamline archival administration pro- } \\
\text { cess and system } \\
\text { Providing archival information to the } \\
\text { wider public } \\
\text { Improving archival collection and man- } \\
\text { agement system }\end{array}$ & No & $\begin{array}{l}\text { http://www.archives. } \\
\text { go.kr/english/activ } \\
\text { ities/vision.jsp }\end{array}$ & \\
\hline
\end{tabular}


Table 4 (Continued)

\begin{tabular}{|c|c|c|c|c|}
\hline Archive & Vision statement & $\begin{array}{l}\text { Time } \\
\text { limit }\end{array}$ & URL & ICA region \\
\hline Japan & 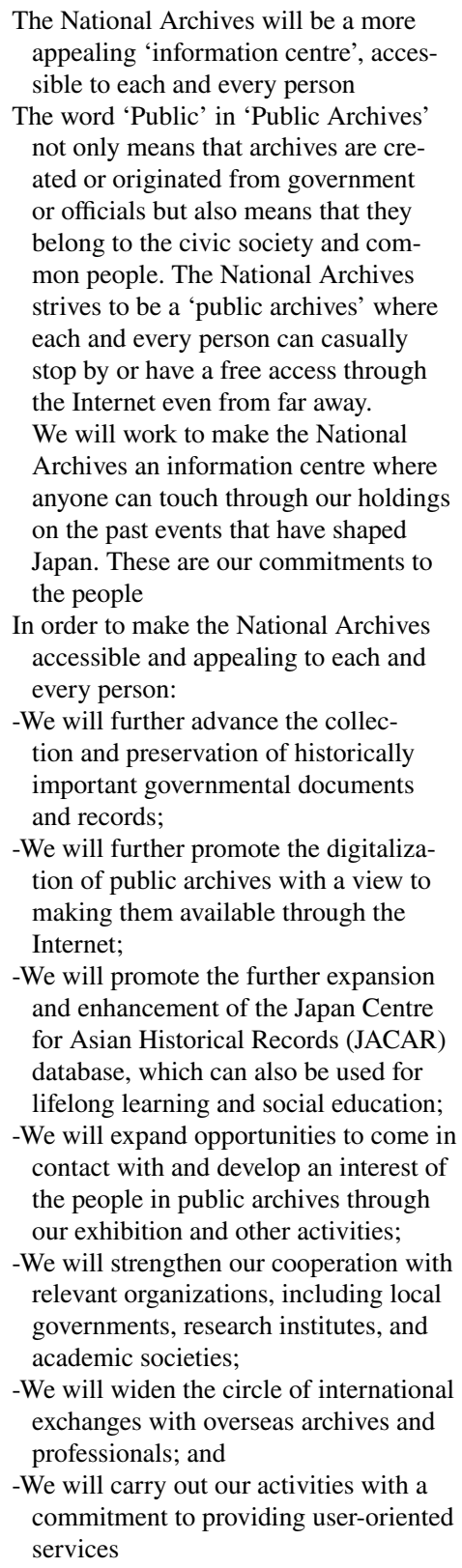 & No & $\begin{array}{l}\text { http://www.archi } \\
\text { ves.go.jp/english/ } \\
\text { abouts/ourvision. } \\
\text { htm }\end{array}$ & \\
\hline
\end{tabular}


Table 4 (Continued)

\begin{tabular}{|c|c|c|c|c|}
\hline Archive & Vision statement & $\begin{array}{l}\text { Time } \\
\text { limit }\end{array}$ & URL & ICA region \\
\hline Ethiopia & $\begin{array}{l}\text { To make the Ethiopian National Library } \\
\text { and Archive Agency one of the five } \\
\text { major African national library and } \\
\text { archive centres by } 2020 \text {, furthering the } \\
\text { culture of using information to build } \\
\text { democracy and development }\end{array}$ & $\begin{array}{l}\text { Yes } \\
\quad(2020)\end{array}$ & $\begin{array}{l}\text { http://www.nala.gov. } \\
\text { et/vision-mission- } \\
\text { value-and-powers }\end{array}$ & ESARBICA \\
\hline Kenya & $\begin{array}{l}\text { To excel as an archives service in view } \\
\text { of all Kenyans, and to serve as the } \\
\text { Memory of the Nation }\end{array}$ & No & $\begin{array}{l}\text { http://www.archives. } \\
\text { go.ke/vision-missi } \\
\text { on/ }\end{array}$ & \\
\hline Mauritius & $\begin{array}{l}\text { Our vision is to meet the challenges of } \\
\text { the twenty-first century as collector, } \\
\text { preserver and provider of informa- } \\
\text { tion in line with modern concepts and } \\
\text { technologies }\end{array}$ & $\begin{array}{l}\text { Yes } \\
\text { (twenty- } \\
\text { first } \\
\text { century) }\end{array}$ & $\begin{array}{l}\text { https://nationalar } \\
\text { chives.govmu.org/ } \\
\text { Pages/About\% } \\
\text { 20Us/Mission- } \\
\text { and-Vision.aspx }\end{array}$ & \\
\hline Namibia & $\begin{array}{l}\text { To provide the nation with a well-docu- } \\
\text { mented and well-preserved collection } \\
\text { of records that reflects the history and } \\
\text { the aspiration of the Namibian people }\end{array}$ & No & $\begin{array}{l}\text { https://nan.gov.na/ } \\
\text { vision-mission }\end{array}$ & \\
\hline Swaziland & $\begin{array}{l}\text { The vision of the Department is to } \\
\text { provide the highest standards Records } \\
\text { and Archives Management Services } \\
\text { and to increase public awareness on the } \\
\text { importance of documentary heritage in } \\
\text { the Swazi nation }\end{array}$ & No & $\begin{array}{l}\text { http://www.gov.sz/ } \\
\text { index.php/minis } \\
\text { tries-departments/ } \\
\text { ministry-of-ict/ } \\
\text { national-archives }\end{array}$ & \\
\hline Finland & $\begin{array}{l}\text { The National Archives of Finland is the } \\
\text { leading expert and information service } \\
\text { organisation in the management of the } \\
\text { lifecycle of public information and } \\
\text { a broad infrastructure for scientific } \\
\text { research. The National Archives } \\
\text { advances the transfer of official and } \\
\text { private materials in electronic format, } \\
\text { the customer-driven digitisation } \\
\text { and diverse use of cultural heritage } \\
\text { documents, data management based } \\
\text { on artificial intelligence and modern } \\
\text { scientific methods, open access to data } \\
\text { and sustainable development }\end{array}$ & No & $\begin{array}{l}\text { https://arkisto.fi/strat } \\
\text { egy } 2025\end{array}$ & EURBICA \\
\hline $\begin{array}{l}\text { North } \\
\text { Macedo- } \\
\text { nia }\end{array}$ & $\begin{array}{l}\text { Research on and accurate depiction of } \\
\text { the generation and historic develop- } \\
\text { ment of the Macedonian nation, } \\
\text { language, history, tradition and culture } \\
\text { to marshal international respect and } \\
\text { credibility }\end{array}$ & No & $\begin{array}{l}\text { http://www.arhiv. } \\
\text { gov.mk/materijali/ } \\
\text { STRATESKIP } \\
\text { LAN_2019-2021. } \\
\text { pdf }\end{array}$ & \\
\hline
\end{tabular}


Table 4 (Continued)

\begin{tabular}{|c|c|c|c|c|}
\hline Archive & Vision statement & $\begin{array}{l}\text { Time } \\
\text { limit }\end{array}$ & URL & ICA region \\
\hline Turkey & $\begin{array}{l}\text { To manage our country's archives from a } \\
\text { single institution and become a world- } \\
\text { wide archival benchmark }\end{array}$ & No & $\begin{array}{l}\text { http://www.devle } \\
\text { tarsivleri.gov.tr/ } \\
\text { Sayfalar/Sayfa/7/ } \\
\text { 7063361CBA } \\
\text { AC3C421E54 } \\
\text { 02D9EED43F } \\
\text { 9CEE1A60EA } \\
\text { AC5D7F217A } \\
\text { 7EB3D3F589 } \\
\text { CC15 }\end{array}$ & \\
\hline $\begin{array}{l}\text { United } \\
\text { Kingdom }\end{array}$ & $\begin{array}{l}\text { We express our organisational values as } \\
\text { 'integrity', 'possibilities' and 'people' }\end{array}$ & No & $\begin{array}{l}\text { https://www.natio } \\
\text { nalarchives.gov. } \\
\text { uk/about/jobs/ } \\
\text { vision-and-values/ }\end{array}$ & \\
\hline USA & $\begin{array}{l}\text { We will be known for cutting-edge } \\
\text { access to extraordinary volumes of } \\
\text { government information and unprec- } \\
\text { edented engagement to bring greater } \\
\text { meaning to the American experience } \\
\text { We collaborate with other Federal } \\
\text { agencies, the private sector, and the } \\
\text { public to offer information-includ- } \\
\text { ing records, data, and context-when, } \\
\text { where, and how it is needed and trans- } \\
\text { form the American public's relation- } \\
\text { ship with their government } \\
\text { We will lead the archival and information } \\
\text { professions to ensure archives thrive in } \\
\text { a digital world }\end{array}$ & No & $\begin{array}{l}\text { https://www.archi } \\
\text { ves.gov/about/ } \\
\text { info/mission }\end{array}$ & NAANICA \\
\hline Australia & $\begin{array}{l}\text { To be a world leading archive in this } \\
\text { digital age }\end{array}$ & No & $\begin{array}{l}\text { https://www.naa. } \\
\text { gov.au/about-us/ } \\
\text { our-organisation/ } \\
\text { accountability- } \\
\text { and-reporting/our- } \\
\text { corporate-plans/ } \\
\text { corporate-plan- } \\
\text { 2019-20-2022-23 }\end{array}$ & PARBICA \\
\hline Fiji Islands & $\begin{array}{l}\text { Uniting Fijians through Authentic and } \\
\text { Accessible Archival Records }\end{array}$ & No & $\begin{array}{l}\text { http://www.archives. } \\
\text { gov.fj/index.php/ } \\
\text { about-us }\end{array}$ & \\
\hline
\end{tabular}


Table 4 (Continued)

\begin{tabular}{|c|c|c|c|c|}
\hline Archive & Vision statement & $\begin{array}{l}\text { Time } \\
\text { limit }\end{array}$ & URL & ICA region \\
\hline $\begin{array}{l}\text { New Zea- } \\
\text { land }\end{array}$ & 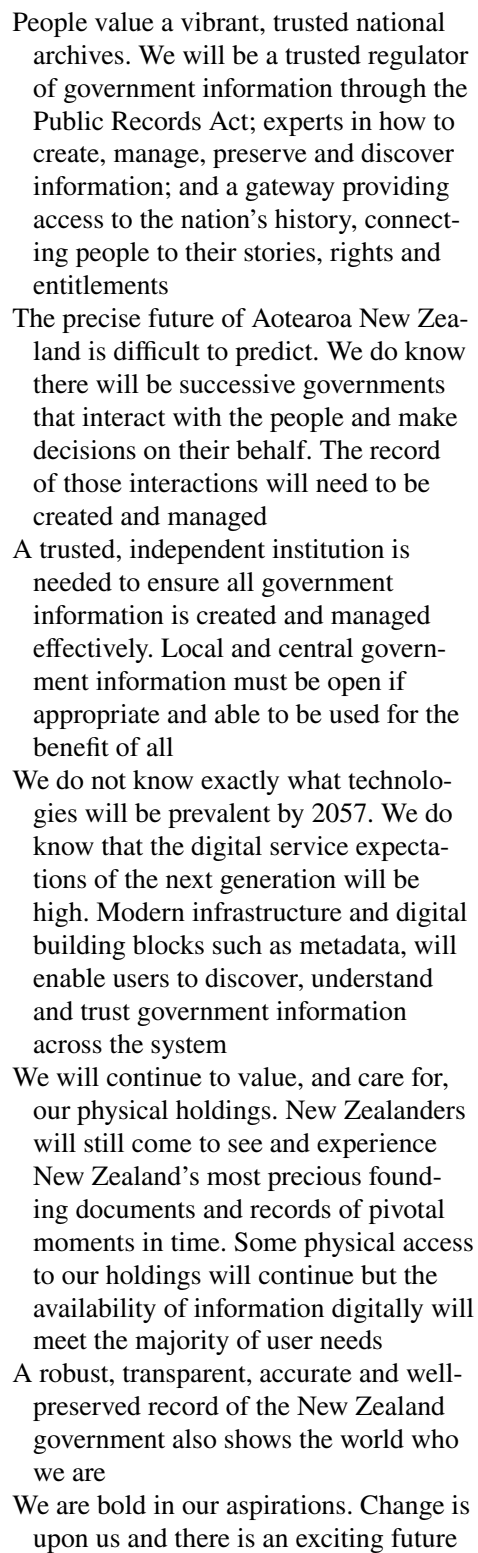 & No & $\begin{array}{l}\text { https://archives.govt. } \\
\text { nz/publications/ } \\
\text { archives-2057- } \\
\text { strategy }\end{array}$ & \\
\hline
\end{tabular}


Table 4 (Continued)

\begin{tabular}{|c|c|c|c|c|}
\hline Archive & Vision statement & $\begin{array}{l}\text { Time } \\
\text { limit }\end{array}$ & URL & ICA region \\
\hline Birmania & Realise the potential & No & $\begin{array}{l}\text { https://www.mopfi. } \\
\text { gov.mm/my/page/ } \\
\text { planning/direc } \\
\text { torate-investment- } \\
\text { company-admin } \\
\text { istration-dica/528 }\end{array}$ & SARBICA \\
\hline Brunei & For a world class museum & No & $\begin{array}{l}\text { http://www.museu } \\
\text { ms.gov.bn/Menge } \\
\text { nai\%20Kami/ } \\
\text { Visi\%20dan\% } \\
\text { 20Misi.aspx }\end{array}$ & \\
\hline Indonesia & $\begin{array}{l}\text { Making the Archive as a Unifying } \\
\text { Nation's Node In The Framework of } \\
\text { Unitary State of the Republic of Indo- } \\
\text { nesia To Be Achieved In } 2025\end{array}$ & $\begin{array}{l}\text { Yes } \\
\quad(2025)\end{array}$ & $\begin{array}{l}\text { https://anri.go.id/en/ } \\
\text { profile/vision-and- } \\
\text { mission }\end{array}$ & \\
\hline Myanmar & Realise the potential & No & $\begin{array}{l}\text { https://www.mopfi. } \\
\text { gov.mm/my/page/ } \\
\text { planning/direc } \\
\text { torate-investment- } \\
\text { company-admin } \\
\text { istration-dica/528 }\end{array}$ & \\
\hline Philippines & $\begin{array}{l}\text { A national records and archives manage- } \\
\text { ment institution firmly committed to } \\
\text { furthering good governance and the } \\
\text { cultural pride of a vibrant, well- } \\
\text { informed, developed and open Philip- } \\
\text { pine society }\end{array}$ & No & Link inoperative & \\
\hline Thailand & $\begin{array}{l}\text { Seeking to be a leader in professional } \\
\text { organisation, archives with standard } \\
\text { management and conservation services }\end{array}$ & No & $\begin{array}{l}\text { https://bit.ly/31sVF } \\
\quad 6 \mathrm{p}\end{array}$ & \\
\hline $\begin{array}{c}\text { Bangla- } \\
\text { desh }\end{array}$ & $\begin{array}{l}\text { To provide information and knowledge } \\
\text { preserved for new generations to build } \\
\text { an intellectual, knowledge-based nation }\end{array}$ & No & $\begin{array}{l}\text { http://www.nanl.gov. } \\
\text { bd/site/page/34dd5 } \\
\text { 48f-a4cc-4c81- } \\
\text { 83c1-b1fffa3d05 } \\
\text { ae/- }\end{array}$ & SWARBICA \\
\hline India & $\begin{array}{l}\text { To help in spreading a feeling of national } \\
\text { pride in our documentary cultural } \\
\text { heritage and ensuring its preservation } \\
\text { for posterity }\end{array}$ & No & $\begin{array}{l}\text { http://nationalar } \\
\text { chives.nic.in/conte } \\
\text { nt/vision-mission }\end{array}$ & \\
\hline Iran & $\begin{array}{l}\text { The National Document and Library } \\
\text { Organisation is the most prominent } \\
\text { centre for the region's knowledge net- } \\
\text { work, with collections, specialists and } \\
\text { alliances for societal knowledge }\end{array}$ & No & $\begin{array}{l}\text { http://www.nlai.ir/ } \\
\text { view }\end{array}$ & \\
\hline Sri Lanka & $\begin{array}{l}\text { Systematic public records management } \\
\text { and conservation as part of the nation's } \\
\text { cultural heritage }\end{array}$ & No & $\begin{array}{l}\text { http://www.archives. } \\
\text { gov.lk/ }\end{array}$ & \\
\hline
\end{tabular}


Table 4 (Continued)

\begin{tabular}{|c|c|c|c|c|}
\hline Archive & Vision statement & $\begin{array}{l}\text { Time } \\
\text { limit }\end{array}$ & URL & ICA region \\
\hline $\begin{array}{l}\text { Cape } \\
\text { Verde }\end{array}$ & $\begin{array}{l}\text { The ANCV's vision is to include, inven- } \\
\text { tory, conserve, restore, digitise, store } \\
\text { and disseminate the collection, making } \\
\text { the National Archive a space for pro- } \\
\text { ducing digital knowledge (digital era), } \\
\text { safeguarding historic memory and our } \\
\text { heritage for future generations whether } \\
\text { in print or digital format, furthering } \\
\text { democratisation of its assets through } \\
\text { the creation of a national archives net- } \\
\text { work, making the ANCV a benchmark } \\
\text { in the valorisation of Cape Verde's } \\
\text { written heritage in-country, among } \\
\text { the diaspora and in the surrounding } \\
\text { communities }\end{array}$ & No & $\begin{array}{c}\text { https://www.arqui } \\
\text { vonacional.cv/? } \\
\text { page_id }=713\end{array}$ & WARBICA \\
\hline Ghana & $\begin{array}{l}\text { A department with professional excel- } \\
\text { lence in records and archival manage- } \\
\text { ment }\end{array}$ & No & $\begin{array}{l}\text { https://praad.gov. } \\
\text { gh/index.php/ } \\
\text { about-us/ }\end{array}$ & \\
\hline
\end{tabular}

Acknowledgements This work was supported by the Ministerio de Ciencia, Innovación y Universidades [RTI2018-095187-B-I00]

Funding Open Access funding provided thanks to the CRUE-CSIC agreement with Springer Nature.

Open Access This article is licensed under a Creative Commons Attribution 4.0 International License, which permits use, sharing, adaptation, distribution and reproduction in any medium or format, as long as you give appropriate credit to the original author(s) and the source, provide a link to the Creative Commons licence, and indicate if changes were made. The images or other third party material in this article are included in the article's Creative Commons licence, unless indicated otherwise in a credit line to the material. If material is not included in the article's Creative Commons licence and your intended use is not permitted by statutory regulation or exceeds the permitted use, you will need to obtain permission directly from the copyright holder. To view a copy of this licence, visit http://creativecommons.org/licen ses/by/4.0/.

\section{References}

Barquero A (2019) Digital Preservation en Latin America. Digital Preservation Coalition https://www. dpconline.org/blog/idpd/la-preservacion-digital-en-latinoamerica. Accessed 15 Oct 2020

Bearman D (1996) NARA issues strategic plan. Arch Museum Inform 10(2):168-172

Berger S (2013) The role of national archives in constructing national master narratives in Europe. Arch Sci 13(1):1-22. https://doi.org/10.1007/s10502-012-9188-z

Bolstad, I. (2019) Re-designing the National Archives of Norway. Designing the Archive International Conference 2019 ICA. https://www.ica.org/sites/default/files/2.4_a_bolstadi.pdf. Accessed 15 Oct 2020

Boadas i Raset J (2006) Archivos: Planificar, gestionar, actuar! [Archives: Planning, Managing and acting] In: Archivo, ¿un servicio público?. Actas I Congreso de Archivos de Canarias, 19-21 de Octubre de 2006, La Oliva, Fuerteventura. Las Palmas de Gran Canaria: Anroart, pp 421-468 
Calder WB (2014) Achieving an institution's Values, Vision and Mission. College Q 17(2). https:// files.eric.ed.gov/fulltext/EJ1038728.pdf. Accessed 15 Oct 2020

Ceeney N (2008) The Role of a 21st-century National Archive-The Relevance of the Jenkinsonian Tradition, and a Redefinition for the Information Society. J Soc Arch 29(1):57-71

Chami M (2017) Community awareness for archives in Tanzania: a Case Study of Zanzibar National Archives . J S Afr Soc Arch 50:56-66

Couture C, Grimard J (2003) Aspects généraux et partuliers de l'administration d'un service d'archives [General and particular aspects of the administration of an archive service]. In: Gagnon-Arguin L, Grimard J (dir.) La gestión d'u centre d'archives. Mélanges en l'honneur de Robert Garon. Presses de 1'Université de Quebec, pp 57-82

Cunningan R, Eddy M, Pagano M, Ncube L (2011) Purdue extended campus: transparency, accountability, and assessment in strategic planning. Contin High Educ Rev 75:153-163

Drucker P (1981) La gerencia: Tareas, responsabilidades y prácticas [Management: Tasks, Responsibilities, Practices]. El Ateneo, Buenos Aires

Espley S, Carpentier F, Pop R, Medjkoune L (2014) Collect, preserve, access: applying the governing principles of the National Archives UK Government Web Archive to social media content. Alexandria 25(1-2):31-50

Evans GE, Alire CA (2013) Management basics for information professionals. Facet Publishing, London

Eze Asogwa B (2011) Digitization of archival collections in africa for scholarly communication: issues, strategies, and challenges. Library Philosophy and Practice (e-journal). Paper 651. http:// digitalcommons.unl.edu/libphilprac/651. Accessed 16 Oct 2020

Friedrich M (2018) Epilogue: archives and archiving across cultures-towards a matrix of analysis. Manus Arch. https://doi.org/10.1515/9783110541397-015

Flyverbom M (2016) Transparency: mediation and the management of visibilities. Int J Commun 10:110-122

Franks PC, Bernier A (eds) (2018) The International Directory of National Archives. Rowman \& Littlefield, Lanham

Garon R (2003) Les Archives nationales [ National Archives]. In: Gagnon-Arguin L, Grimard J (dir.) La gestión d’u centre d’archives. Mélanges en 1’honneur de Robert Garon. Presses de l’Université de Quebec, pp 225-247

Guccio C, Martorana MF, Mazza I, Rizzo I (2016) Technology and public access to Cultural Heritage: The Italian Experience on ICT for Public Historial Archives. In Borowiecki KJ et al (eds) Cultural Heritage in a Changing World. Springer, New York, pp 55-75. https://doi.org/10.1007/ 978-3-319-29544-2_4

Herstad J (1998) Ny strategiplan for det norske arkivverket. New strategic plan for the Norwegian archive service. Nordisk Arkivnyt 43(1):16-17

Huot C, Gareau A (2003) Planification stratégique et gestión des operations [ Strategic planning and operations management]. In: Gagnon-Arguin L, Grimard J (dir.) La gestión d’u centre d'archives. Mélanges en 1’honneur de Robert Garon. Presses de 1’Université de Quebec, pp 85-107

ICA (International Council Archives) (2008) ICA: Strategic Direction 2008-2018. https://www.ica. org/sites/default/files/AGM_2008-07-25_strategic\%20direction_EN.pdf. Accessed 16 Oct 2020

ICA (International Council Archives) (2010) Business Plan 2009-2010 (as at May 2010) https://www. ica.org/sites/default/files/EB_2010-06_Business-plan-revision-June-2010_EN.pdf. Accessed 16 Oct 2020

ICA (International Council Archives) (2015) Africa Strategy. https://www.ica.org/sites/default/files/ ICA\%20Africa\%20Strategy\%20EN.pdf. Accessed 16 Oct 2020

IFLA (International Federation of Library Associations) (2002). Guidelines for digitization projects for collections and holdings in the public domain, particularly those held by libraries and archives.http://www.atlaskulturnebastine.rs/download/IFLA_Guidelines_for_Digitization_Proje cts.pdf. Accessed 19 Oct 2020

Jang H-J (2012) A study on evaluation of National Archives Websites. J Korean Soc Arch Records Manag 12(2):51-70

Kantabutra S, Avery GC (2010) The power of vision: statements that resonate. J Bus Strategy 31(1):37-45. https://doi.org/10.1108/02756661011012769 
Karabinos M (2018) Archives and post-colonial state-sponsored history: a dual state approach using the case of the "Migrated Archives." In: Bevernage B, Wouters N (eds) The Palgrave handbook of state-sponsored history after 1945. Palgrave Macmillan, London, pp 177-190

Kirkpatrick SA, Wofford JC, Robert Baum J (2002) Measuring motive imagery contained in the vision statement. Leadershiq 13(2):139-150

Kostagiolas PA, Banou C, Laskari E (2009) Strategic planning and management for the public libraries: The case of Greek central public libraries. Libr Manag 30(4/5):253-265. https://doi.org/10. $1108 / 01435120910957913$

Landau D, Drori L, Porras J (2006) Vision change in a government R\&D organization. J Appl Behav Sci 42(2):145-171

Marco GA (1996a) The terminology of planning: part 1. Libr Manag 17(2):17-23. https://doi.org/10. 1108/01435129610108234

Marco GA (1996b) The terminology of planning: part 2. Libr Manag 17(7):17-24. https://doi.org/10. $1108 / 01435129610128331$

McKay, S (2003) Digitization in an archival environment. Electron J Acad Spec Librariansh. 19992009 1-10(31). https://digitalcommons.unl.edu/ejasljournal/31 Accessed 19 Oct 2020

Ministerio de la Presidencia, España (2013) Ley 19/2013 de 9 de diciembre, de Transparencia, Acceso a la Información Pública y Buen Gobierno [Law 19/2013 of December 9, on Transparency, Access to Public Information and Good Governance] www.boe.es/buscar/act.php?id=BOE-A2013-12887. Accessed 20 Oct 2020

The National Archives (n.d.) Planning. https://www.nationalarchives.gov.uk/information-manag ement/manage-information/planning/. Accessed 21 Oct 2020

Newton C (1984) Strategic planning for records management and archives. Society of Archivists, Winchester

Ngulube P, Tafor VF (2006) The management of public records and archives in the member countries of ESARBICA. J Soc Arch 27(1):57-83. https://doi.org/10.1080/00039810600691288

Onuoha UD (2013) Awareness and use of the national archives in Nigeria. IOSR J Res Method Educ 3(4):64-68

Otu BO, Asante E (2015) Awareness and use of the national archives: evidence from the Volta and Eastern Regional Archives, Ghana. Brazilian J Inform Sci: Res Trends 9(2):21-26

Özdem G (2011) An analysis of the mission and vision statements on the strategic plans of higher education institutions. Educ Sci: Theory Pract 11(4):1887-1894

Pacios AR (2004) Strategic plans and long-range plans: is there a difference? Libr Manag 25(6):259-269

Pacios AR (2007) The priorities of public libraries at the onset of the third millennium. Libr Manag 28(6/7):416-427. https://doi.org/10.1108/01435120710774549

Pacios AR, Martínez Cardama S (2019) European National Libraries' strategy. Library Philosophy and Practice (ejournal) 2630. https://core.ac.uk/download/pdf/228383103.pdf. Accessed 21 Oct 2020

Riggs D (1998) Visionary leadership. In: Mech TF, McCabe GB (eds) Leadership and academic librarianship. Greenwood Press, Westport

Saurombe N (2020) Taking archives to the people: an examination of public programs in the National Archives of the Eastern and Southern Africa Regional Branch of the International Council on Archives. Arch Manuss 48(1):25-44. https://doi.org/10.1080/01576895.2019.1604242

Seo HG (2010) Toward a revitalization of the children's education programs at the National Archives of Korea. J Korean Soc Arch Records Manag 10(1):141-167

Seol M-W (2008) A study of strategic planning for archival information services in the National Archives of Korea. J Korean Soc Inform Manag 25(3):249-271

Shipley R, Michela JL (2006) Can vision motivate planning action? Plan Pract Res 21(2):223-244. https://doi.org/10.1080/02697450600944715

Titscher S, Meyer M, Wodak R, Vetter E (2000) Methods of text and discourse analysis. SAGE, London

Thornberry N (1997) A view about vision. Eur Manag J 15(1):28-34

Venson SL, Ngoepe M, Ngulube P (2014) The role of public archives in national development in selected countries in the East and Southern Africa Regional Branch of the International Council on Archives region . Innov: J Approp Librariansh Inform Work South Afr 48:46-68 
Voutssas J (2012) Long-term digital information preservation: challenges in Latin America. Aslib Proc 64(1):83-96. https://doi.org/10.1108/00012531211196729

Williams C (2006) Managing archives: foundations, principles and practice. Chandos Publishing, Oxford

Wilson I (2018) Foreword. In: Franks PC, Bernier A (eds) The International Directory of National Archives. Rowman \& Littlefield, London, p 9

Wilsted T, Nolte W (1991) Managing archival and manuscript repositories. Society of American Archivists Archivist, Chicago

Publisher's Note Springer Nature remains neutral with regard to jurisdictional claims in published maps and institutional affiliations. 